$K-25$

\section{OAK RIDGE K-25 SITE}

LOCKHEED MATTINA
FEB 141996

OSTI

\section{TREATABILITY STUDY FOR REMOVAL OF LEACHABLE MERCURY IN CRUSHED FLUORESCENT LAMPS}

\section{MANAGED BY}

LOCKHEED MARTIN ENERGY SYSTEMS, INC. FOR THE UNITED STATES DEPARTMENT OF ENERGY
February 1996

Pepared by the Oak Ridge K-25 Site

Oak Ridge, Tennessee 37831-7133

managed by

LOCKHEED MARTIN ENERGY SYSTEMS, INC.

for the

U.S. DEPARTMENT OF ENERGY

under contract DE-AC05-84OR21400

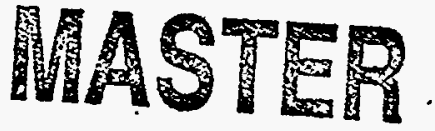

DIGTRIBUTION OF THAS DOCUMENT IS UNLIMTED TR 


\section{DISCLAIMER}

This report was prepared as an account of work sponsored by an agency of the United States Government. Neither the United States Government nor any agency or agent thereof, nor any of their employees, makes any warranty, express or implied, or assumes any legal liability or responsibility for the accuracy, completeness, or usefulness of any information, apparatus, product, or process disclosed, or represents that its use would not infringe privately owned rights. Reference herein to any specific commercial product, process, or service by trade name, trademark, manufacturer, or otherwise, does not necessarily constitute or imply its endorsement, recommendation, or favoring by the United States Government or any agency or agent thereof. The views and opinions of authors expressed herein do not necessarily state or reflect those of the United States Government or any agency thereof. 
FEB 141990

\section{OSTI}

\section{OAK RIDGE K-25 SITE}

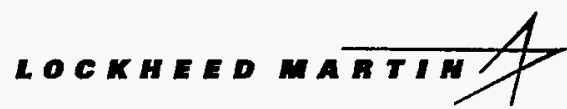

MANAGED BY

LOCKHEED MARTIN ENERGY SYSTEMS, INC.

FOR THE UNITED STATES

DEPARTMENT OF ENERGY
TREATABILITY STUDY FOR REMOVAL OF LEACHABLE MERCURY IN CRUSHED FLUORESCENT LAMPS

February 1996

Pepared by the Oak Ridgc K-25 Site

Oak Ridge, Tennessee 37831-7133 managed by LOCKHEED MARTIN ENERGY SYSTEMS, INC. for the U.S. DEPARTMENT OF ENERGY under contract DE-AC05-84OR21400

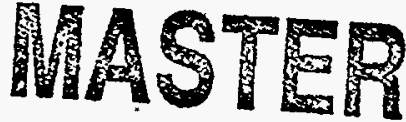

DISTRIBUTION OF THHS DOCUMENT IS UNLIMTED JRR 


\section{DISCLAIMER}

This report was prepared as an account of work sponsored by an agency of the United States Government. Neither the United States Government nor any agency or agent thereof, nor any of their employees, makes any warranty, express or implied, or assumes any legal liability or responsibility for the accuracy, completeness, or usefulness of any information, apparatus, product, or process disclosed, or represents that its use would not infringe privately owned rights. Reference herein to any specific commercial product, process, or service by trade name, trademark, manufacturer, or otherwise, does not necessarily constitute or imply its endorsement, recommendation, or favoring by the United States Government or any agency or agent thereof. The views and opinions of authors expressed herein do not necessarily state or reflect those of the United States Government or any agency thereof. 


\title{
TREATABILITY STUDY FOR REMOVAL OF LEACHABLE MERCURY IN CRUSHED FLUORESCENT LAMPS
}

\author{
W. D. Bostick \\ D. E. Beck \\ K. T. Bowser \\ D. H. Bunch \\ R. L. Fellows \\ G. F. Sellers
}

February 1996

\author{
Pepared by \\ the Oak Ridge K-25 Site \\ Oak Ridge, Tennessee 37831-7133 \\ managed by \\ LOCKHEED MARTIN ENERGY SYSTEMS, INC. \\ for the \\ U.S. DEPARTMENT OF ENERGY \\ under contract DE-AC05-84OR21400
}


. 


\section{CONTENTS}

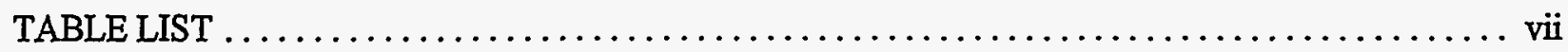

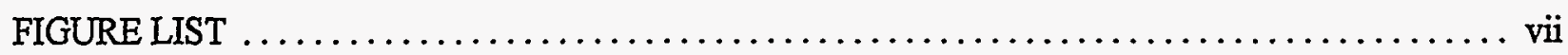

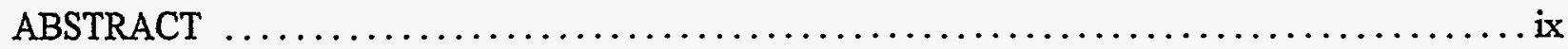

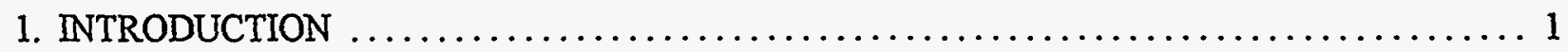

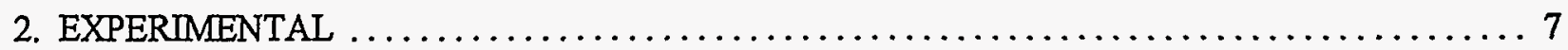

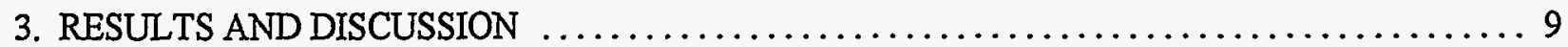

3.1 Characterization of Waste from Storage Inventory $\ldots \ldots \ldots \ldots \ldots \ldots \ldots \ldots \ldots \ldots$

3.2 Investigations in Support of the Proposed Treatment Flowsheet .................. 11

3.3 RCRA Treatability Studies in Support of Proposed Treatment Flowsheet . . . . . . . . 26

3.4 Preliminary Investigations in Support of an Alternate Treatment Flowsheet . . . . . . . . 29

3.5 Proposed Apparatus for Pilot-Scale Treatability Demonstration ............... 31

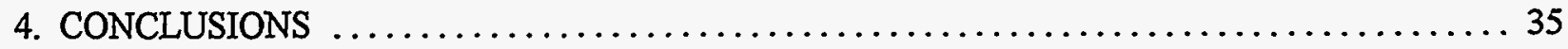

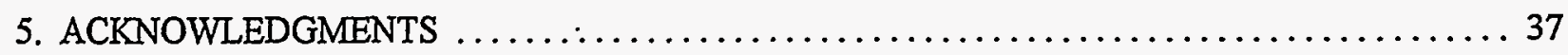

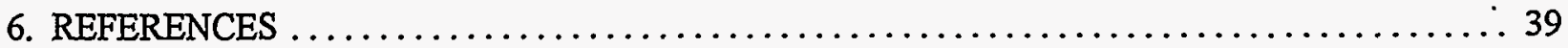




\section{TABLE LIST}

Table 1. Data for TCLP extraction of crushed fluorescent lamps stored at the K-25 Site ...... i0

Table 2. Treatment technology effectiveness for mercury in plating wastewater $\ldots \ldots \ldots \ldots \ldots 17$

Table 3. Selected standards electrode potentials for acidic aqueous solutions at $25^{\circ} \mathrm{C} \ldots \ldots \ldots 17$

Table 4. Summary of conditions for packed-column breakthrough studies using Kodak

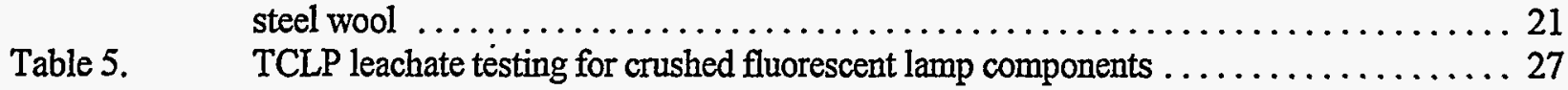

\section{FIGURE LIST}

Fig. 1. Schematic representation of a fluorescent lamp showing approximate lamp mass

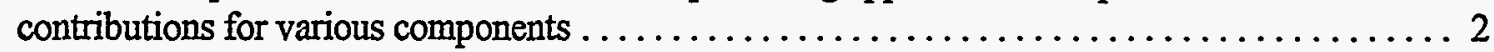

Fig. 2. Process flow sheet for solubilizing mercury from crushed fluorescent lamps with subsequent recovery of mercury by selective sorption. $\ldots \ldots \ldots \ldots \ldots \ldots \ldots \ldots \ldots \ldots$

Fig. 3. Removal of soluble mercury with use of various media $\ldots \ldots \ldots \ldots \ldots \ldots \ldots \ldots \ldots \ldots$

Fig. 4. Comparison of Rotex steel wool and Duolite GT-73 resin for the removal of trace soluble mercury from de-ionized water and from $7.5 \mathrm{wt} \%$ sodium chloride solution $\ldots \ldots \ldots \ldots .15$

Fig. 5. Comparison of metal wool products for removal of $\mathrm{HgCl}_{2}$ in distilled water at

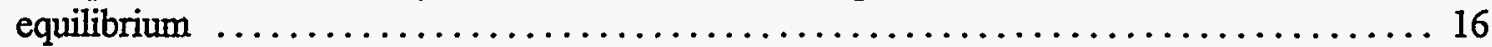

Fig. 6. Chemical recovery cartridges, containing steel wool reagent $\ldots \ldots \ldots \ldots \ldots \ldots \ldots \ldots \ldots$

Fig. 7. Removal of soluble technetium-99 from carbonate solution by zero-valent iron and selected anion-exchange resins as a finction of equilibrium solution $\mathrm{pH}$ value $\ldots \ldots \ldots \ldots \ldots \ldots 20$

Fig. 8. Breakthrough of complexed mercury from glass columns packed with steel wool ........23

Fig. 9. Beads of elemental mercury after breakthrough in a packed column of steel wool ........ 25

Fig. 10. Proposed process flowsheet to remove mercury-containing phosphor particulate from crushed fluorescent lamps by rinsing with water containing a mild reducing agent $\ldots \ldots 30$

Fig. 11. Flow sheet of proposed redox treatment processed for removal of mercury from crushed fluorescent lamps 



\begin{abstract}
Nonserviceable fluorescent lamps removed from radiological control areas at the Oak Ridge Department of Energy facilities have been crushed and are currently managed as mixed waste (hazardous and radiologically contaminated). We present proposed treatment flowsheets and supporting treatability study data for conditioning this solid waste residue so that it can qualify for disposal in a sanitary landfill. Mercury in spent fluorescent lamps occurs primarily as condensate on high-surface-area phosphor material. It can be solubilized with excess oxidants (e.g., hypochlorite solution) and stabilized by complexation with halide ions. Soluble mercury in dechlorinated saline solution is effectively removed by cementation with zero-valent iron in the form of steel wool. In packed column dynamic flow testing, soluble mercury was reduced to mercury metal and insoluble calomel, loading $>1.2$ $\mathrm{g}$ of mercury per gram of steel wool before an appreciable breakthrough of soluble mercury in the effluent.
\end{abstract}




\section{INTRODUCTION}

Modern fluorescent lamps consist of a sealed glass envelope, internally coated with a phosphor material (usually 3-20- $\mu \mathrm{m}$ calcium halophosphate particles, doped with trace antimony ( $\mathrm{Sb}$ ) and/or manganese $(\mathrm{Mn}$ ) activators), with an electrode assembly at each end (see Figure 1). The phosphor material converts ultraviolet light, produced by a low pressure mercury $(\mathrm{Hg})$ arc, into visible light (Butler 1980). A typical 48-inch (122-cm) fluorescent lamp (cool white, type F40T12), weighing $\sim 290 \mathrm{~g}$, may contain 27-48 mg of mercury (or a total mercury (Hg) content 93-166 mg/kg, with newer lamps having less mercury) (Meyer 1992). The glass envelope represents the preponderance ( $\sim 90 \%)$ of total lamp mass, but the high surface area phosphor component offers the greatest opportunity for condensation or sorption of mercury. According to industry sources (Foust 1994), the phosphor component, which represents less than $2 \%$ of the total lamp mass, may contain $~ 80 \%$ of the total mercury content; thus, the concentration of mercury associated with the phosphor component can be several thousand $\mathrm{mg} / \mathrm{kg}$ [a typical value in used lamp phosphor powder is $\sim 4700 \mathrm{mg} \mathrm{Hg} / \mathrm{kg}$ (Truesdale et al., 1993, U.S. EPA 1994)]. Endcaps (predominantly aluminum) with leaded glass and filaments together represent the balance (about $8 \%$ ) of the lamp mass.

Approximately 600 million fluorescent lamps are disposed of each year (Truesdale et al. 1993). Nonfunctional (spent) mercury-containing lamps may be considered hazardous waste under the Toxicity Characteristic Regulation issued under the Resource Conservation and Recovery Act (RCRA) provisions of the U.S. Environmental Protection Agency (EPA) [40 CFR Parts 260, 261, and 273]. If so, these lamps must be managed as hazardous waste. The EPA Toxicity Characteristic Leaching Procedure (TCLP) testing protocol is used to define the potential for select toxic constituents to leach out of the waste, simulating conditions that may exist for disposal of solid waste in an unlined sanitary landfill. Crushed fluorescent lamps evaluated by the TCLP testing protocol often fail the defining toxicity criterion for $\mathrm{Hg}$ (i.e., $20.2 \mathrm{mg} / \mathrm{L}$ in the leachate solution) (Meyer 1992), and may be classified as RCRA waste code D009 (characteristically hazardous due to the concentration of mercury in the leachate). To qualify for land disposal, waste failing the TCLP toxicity criterion must be conditioned to meet the Universal Treatment Standard (UTS; see 59 FR 47982, September 19, 1994); for mercury, the UTS criterion is $0.025 \mathrm{mg} / \mathrm{L}$ in the TCLP leachate.

Approximately 80,000 fluorescent lamps are replaced each year at the U. S. Department of Energy's three sites in Oak Ridge, Tennessee, (Oak Ridge National Laboratory, the Y-12 Plant, and the K-25 Site). Recently (August 1995), the Tennessee Department of Environment and Conservation indicated that intact lamps, managed for purposes of recycling/reclamation, may be considered to be characteristic by-products, and as such are conditionally exempt from strict regulation under RCRA Subtitle $C$ as characteristically hazardous waste. These lamps are eligible for off-site shipment for reclamation of mercury and other lamp components. 


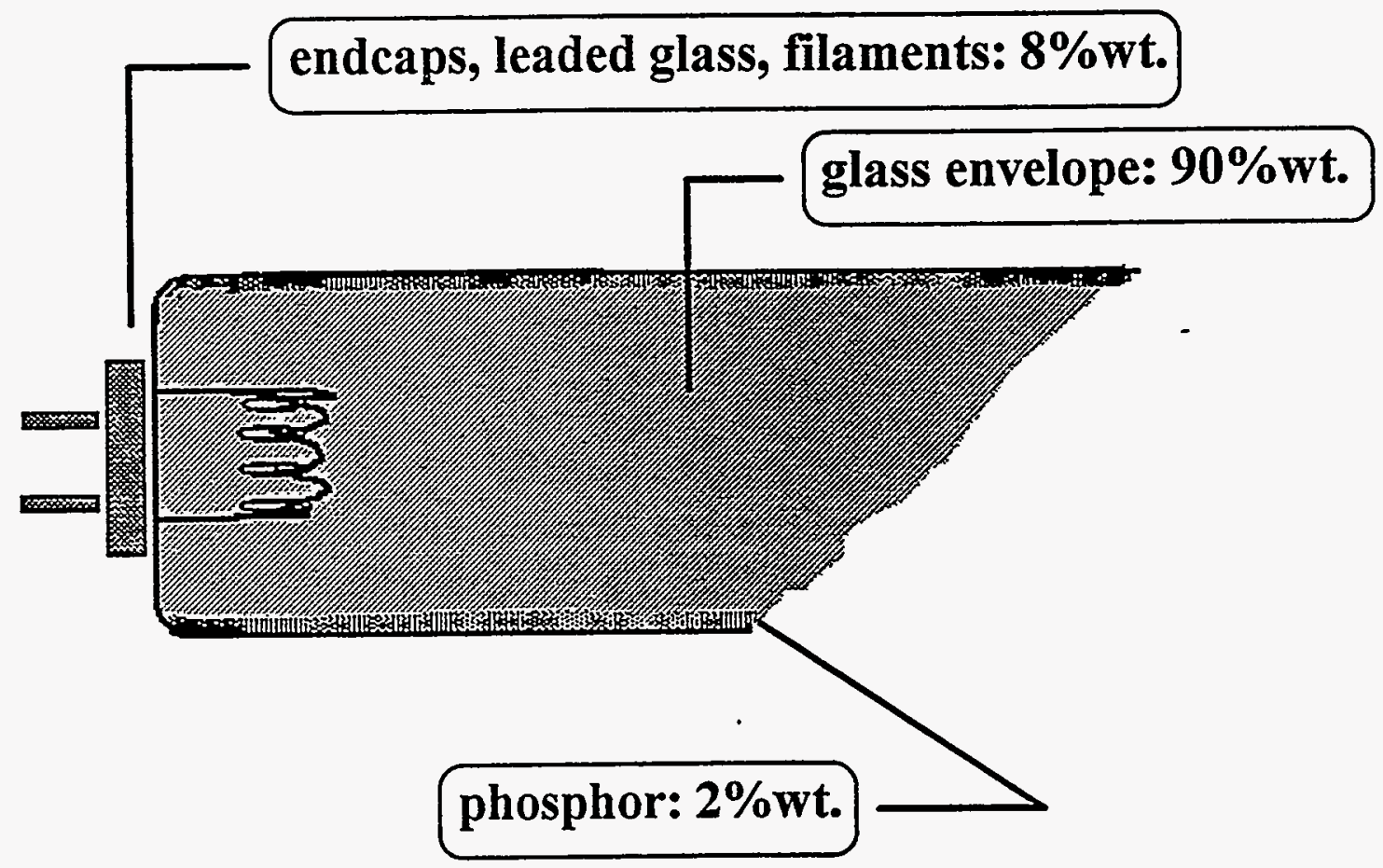

Figure 1. Schematic representation of a fluorescent lamp showing approximate lamp mass contributions for various components. 
However, by K-25 Site policy (Standard Practice Procedure IAD-SPP-3008), broken or crushed lamps continue to be managed as hazardous waste, and crushed lamps that were removed from radiologically contaminated areas are managed as mixed (hazardous and radiological) waste. Included in the latter category is an inventory of $\sim 1000$ sealed 55-gallon drums of previously crushed lamps (a total of $~ 165,000 \mathrm{~kg}$ of waste) currently in permitted storage at the K-25 Site.

We describe a treatability study to identify a process for conditioning the inventory of crushed lamps to yield a solid residue that qualifies for permitted disposal at the Y-12 Plant Sanitary Landfill, while producing a minimal volume of treatment residues that must still be handled as a potential mixed waste. This would free up much-needed permitted vault storage space for other priority mixed wastes. Options for removing mercury from wastes include thermal desorption ("Best Demonstrated Available Technology" for hazardous high-level mercury wastes; 40 CFR 268.41). Some commercial lamp recycling facilities use thermal processing (roasting or retorting) to reclaim mercury; although this approach can be effective, it places a burden on the engineered control of fugitive emission and/or off-gas, and may generate substantial secondary waste. For use in on-site treatment, an alternative aqueous extraction process flowsheet is attractive, since the conditioned effluent (after mercury removal) could be discharged in a regulatory compliant manner. The Central Neutralization Facility (CNF) at the K-25 Site treats aqueous hazardous and radiological waste by iron co-precipitation for release to the surface water through a monitored and permitted National Pollutant Discharge and Elimination System.

The process flowsheet discussed in this paper (Figure 2) consists of (1) solubilization of mercury by aqueous extraction or leaching; (2) liquid/solid phase separation; (3) liquid phase preconditioning (e.g., $\mathrm{pH}$ adjustment, dechlorination); and (3) recovery of mercury from the spent leachant solution (by sorption or reduction, to yield a minimal volume of contaminated solid waste). The mercury-depleted leachate will be polished by treatment at the CNF prior to discharge.

Gates and co-workers (1995) investigated several combinations of chemical agents for removal of mercury from solid mixed wastes: oxidants (to convert elemental mercury to soluble mercuric ion), acid (to prevent hydrolysis, and precipitation, of $\mathrm{Hg}^{++}$), and complexants (to stabilize mercuric ions in solution phase). They supplemented the glass/phosphor component of crushed fluorescent lamps with additional $\mathrm{Hg}^{0}$, and determined recovery in the acidic leachant solution; two reagent systems were determined to be especially effective for recovery (>98\%) of dosed mercury: potassium iodide/iodine $\left(\mathrm{K} / \mathrm{I}_{2}\right)$ and sodium hypochlorite (NaOCl). The $\mathrm{KI} / I_{2}$ system for mercury removal has been patented by the General Electric Corporation (Foust, 1993). The use of hypochlorite (OCl; the active ingredient in household "bleach") to solubilize mercury is more 'generic' technology; for example, it has been used successfully to leach mercury from sludges and residues (Rockandel, 1992; Pedroso et al., 1994). 


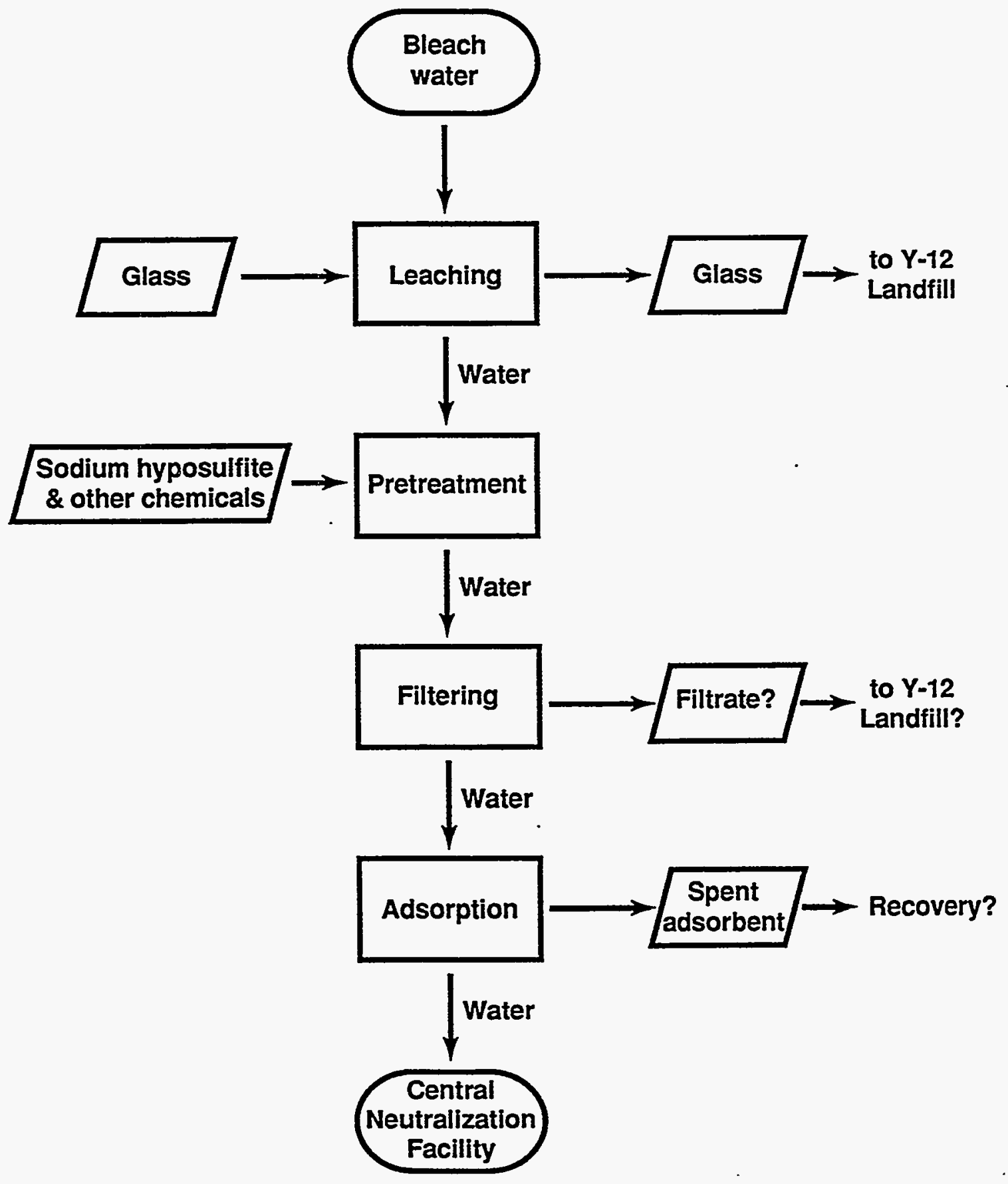

Figure 2. Process flow sheet for solubilizing mercury from crushed fluorescent lamps with subsequent recovery of mercury by selective sorption. 


$$
\mathrm{Hg}+\mathrm{Cl}^{-}+\mathrm{ClO}^{-}+\mathrm{H}_{2} \mathrm{O} \rightarrow \mathrm{HgCl}_{2}(\mathrm{aq})+2 \mathrm{OH}^{-}
$$

After the mercury has been solubilized, it must be removed from solution before the leachate can be released to the environment. It is desirable to recover the mercury in a concentrated form, to minimize the volume of hazardous secondary waste material for storage and/or to facilitate ultimate resource recovery. For hypochlorite leachate, preconditioning may include dechlorination (i.e., removal of excess oxidants that may interfere with sorption of mercury) and $\mathrm{pH}$ adjustment. Selective sorbants or reductants can be used to concentrate mercury from the dilute solution. We tested several candidate materials, including sulfur-impregnated carbons and organic ion exchange resins, but found metal wools (copper or iron) to be especially effective and economical. Iron metal (or steel) is inexpensive and environmentally friendly (nontoxic). Steel wool has been used in commercial applications to recover silver metal from spent photographic developer reagent waste; a galvanic reaction with the zero-valence iron reduces the complexed silver, which plates out in a greatly concentrated form suitable for subsequent resource recovery (Hess, 1992). In related work, we have found iron filings and steel wool to be effective reagents for removing radioactive ${ }^{99} \mathrm{Tc}(\mathrm{VII})$, and other contaminants such as $\mathrm{Cr}(\mathrm{VI})$, etc., from aqueous solution (Bostick et al. 1995a). 


\section{EXPERIMENTAL}

\section{Microscopic Examination}

Elemental distributions of mercury and lead in solids and sludges were determined by Energy-Dispersive $\mathrm{X}$-ray Spectroscopy (EDS), using an Electroscan environmental scanning electron microscope. This instrumentation is capable of operation at relatively high pressures (5-50 torr) and at subambient temperatures. These conditions are favorable for the retention of relatively volatile mercury, which could be lost with use of conventional ambient temperature, high-vacuum instrumentation. By back-scatter imaging, heavy elements (such as mercury) give bright images, and can be readily discriminated from lighter elements (e.g., aluminum, silicon, calcium etc.) in the sample matrix.

\section{TCLP Testing}

All TCLP testing was performed by the K-25 Site Analytical Services Organization, using the approved EPA Method 1311 protocol. Sample data are archived by unique Analytical Laboratory Information System (AnaLIS) identification numbers (see Appendix A).

\section{Quantitation of Mercury}

Solutions submitted to Analytical Services were analyzed by cold vapor atomic absorption spectroscopy (EPA Method 7470). Some developmental samples were analyzed in-house using conventional atomic absorption . spectroscopy. For rapid and sensitive determination of mercury sorption isotherms and packed-column breakthrough performance, we traced aqueous solutions of natural mercuric ions with ${ }^{203} \mathrm{Hg}$, a gamma-emitting isotope with a radioactive half-life of 46.9 days. The tracer was obtained from Amersham International as a mercuric chloride solution (Product UC0751). Traced solutions were counted in a Packard Auto-gamma 500C radiation measurement system, and the results were corrected for radioactive decay.

\section{Sorbents}

The following sorbent materials were tested for their effectiveness in the removal of soluble mercury (as $\mathrm{HgCl}_{2}$ in aqueous solution):

* Duolite GT 73 mercury-selective cation exchange resin, from Rohm and Haas, Philadelphia Pennsylvania; 
* Nucon Nusorb Mersorb-3 and Kina-3 granular activated carbon products, from Nuclear Consulting Services, Columbus Ohio;

* HGR sulfonated carbon from Calgon, Pittsburgh, Pennsylvania;

* Decolorizing carbon, Norit A (alkaline), from Fisher Chemical, Fairborough, New Jersey;

* Pulverized ASTM A518 high silicon steel , from Duriron Co., Dayton, Ohio;

* Coarse copper wool (strand diameter $\sim 43 \mu \mathrm{m}$ ), 'Elephant Brand', from International Steel Wool, Springfield, Ohio;

* $\quad$ Pro's Best \# 1 medium steel wool, from International Steel Wool, Springfield Ohio;

* Medium steel wool, from Rotex Silver Recovery Co., Springfield, Ohio;

* Coarse steel wool (strand diameter $\sim 93 \mu \mathrm{m}$; removed from Chemical Recovery Cartridge II, catalog no. 173-4953), from Eastman Kodak, Rochester, New York.

\section{Sorption Isotherm Testing}

The techniques used are described in Bostick et al. (1995A, B). In summary, an accurately measured mass of sorbent and a measured aliquot of radiologically traced test solution are equilibrated in a glass vial for 16-24 hours on a Burrell wrist action shaker. Measured aliqouts of equilibrated liquid phase, filtered through $0.2-\mu \mathrm{m}$ pore membrane media, are counted to determine activity.

\section{Column Breakthrough Studies .}

The techniques and apparatus used are described in Bostick et al. (1995B). Traced test solution was metered up through the sorbent medium packed in glass tubes with use of a calibrated peristaltic pump. Discrete effluent aliquot samples were collected directly into gamma-counting tubes at defined intervals using a programmable fraction collector. The aliquots were counted off-line, and the measured activity corrected for isotopic decay. 


\section{RESULTS AND DISCUSSION}

\subsection{Characterization of Waste from Storage Inventory}

\section{TCLP Testing of Crushed Fluorescent Lamps Stored at K-25 Site}

Table 1 summarizes testing results for crushed lamp material sampled from inventoried waste. For these particular composite samples, the TCLP criterion for mercury $(0.20 \mathrm{mg} / \mathrm{L})$ was not exceeded; assuming a normal distribution of results for the seven sampling events, the median result for $\mathrm{Hg}$ in the TCLP leachate was $(0.076$ $\pm 0.05) \mathrm{mg} / \mathrm{L}$. However, sampling and analysis of similar crushed lamps stored at the Y-12 Plant yielded an average $\mathrm{Hg}$ content in the TCLP extract of $(0.27 \pm 0.16) \mathrm{mg} / \mathrm{L}$, with 7 of the 13 composite samples failing the toxicity criterion. Limited toxicity testing of fluorescent lamps at Oak Ridge National Laboratory, delivered to the laboratory intact before size reduction for TCLP, yielded Hg content in the TCLP extract of $(0.29 \pm 0.28)$ $\mathrm{mg} / \mathrm{L}$, with 4 of 10 lamps tested failing the toxicity criterion. Meyer (1992) has reported on the wide range of interlaboratory TCLP test results for fluorescent lamps but concludes that the testing consensus supports the handling of spent lamps as hazardous waste (see Appendix B).

\section{Uranium Content of Crushed Fluorescent Lamps Stored at the K-25 Site}

The previously described samples for TCLP testing were analyzed for total uranium (U) content (fluorimetric analysis), but no uranium was detected $(<1.0 \mathrm{mg} / \mathrm{g}$ ). The specific activity (SA) of uranium is a function of the isotopic distribution, which could not be determined in the low-uranium samples. Assuming natural uranium with SA $6.86 \times 10^{-7} \mathrm{Ci} / \mathrm{g}$, a background uranium content of $1 \mu \mathrm{g} / \mathrm{g}$ corresponds to an activity of $\sim 0.7 \mathrm{pCi} / \mathrm{g}$. The Waste Acceptance Criteria for the $\mathrm{Y}-12$ Industrial Landfill specifies that uranium must not be present in wastes at activities $>35 \mathrm{pCi} / \mathrm{g}$ (local background activity).

\section{Total Mercury Content in a Subsample of Crushed Fluorescent Lamps Stored at the K-25 Site}

A 5-gallon composite subsample was received for RCRA Treatability Study testing. The drum was cooled (to minimize possible loss of mercury by volatilization), and the contents were subdivided into a number of sealed glass containers for use in subsequent testing. Examination of identifying markings on the glass shards indicated that the material originated from lamps produced by a variety of manufacturers. To gain a figure of merit for mercury content, samples of glass envelope with attached phosphor were analyzed [by EPA Method 7471: Mercury in Solid or Semisolid Waste (Manual Cold-Vapor Technique)]; two subsamples gave estimates of 66 and $91 \mu \mathrm{g} / \mathrm{g}$ (or an average mercury content of $\sim 80 \mu \mathrm{g} / \mathrm{g}$ ). This data appears fairly 
TABLE 1. DATA FOR TCLP EXTRACTION OF CRUSHED

FLUORESCENT LAMPS STORED AT THE K-25 SITE

(RESULTS GIVEN AS MG/L IN EXTRACT)

\begin{tabular}{|c|c|c|c|c|c|c|c|c|c|}
\hline AnaLIS ID $^{a}$ & Mercury $^{b}$ & Lead $^{\circ}$ & Arsenic $^{\circ}$ & Barium $^{\circ}$ & Cadmium $^{c}$ & Chromium $^{c}$ & Nickel ${ }^{\circ}$ & Selenium $^{c}$ & Silver $^{c}$ \\
\hline $940608-124$ & 0.033 & 1.0 & $<0.25$ & 0.73 & $<0.015$ & $<0.05$ & 0.97 & $<0.25$ & $<0.035$ \\
\hline $940608-123$ & 0.11 & 1.4 & $<0.25$ & 7.2 & $<0.015$ & 0.17 & 14 & $<0.25$ & $<0.035$ \\
\hline $940608-121$ & 0.056 & 1.1 & $<0.25$ & 1.1 & $<0.015$ & $<0.05$ & 1.6 & $<0.25$ & $<0.035$ \\
\hline $940608-122$ & 0.066 & 0.43 & $<0.25$ & 0.75 & $<0.015$ & 0.091 & 0.53 & $<0.25$ & $<0.035$ \\
\hline $940608-119$ & 0.065 & $<0.25$ & $<0.25$ & 4.2 & $<0.015$ & 0.23 & 9.8 & $<0.25$ & $<0.035$ \\
\hline $940608-120$ & 0.031 & $<0.25$ & $<0.25$ & 1.1 & $<0.015$ & $<0.05$ & 1.3 & $<0.25$ & $<0.035$ \\
\hline $910115-070$ & 0.169 & 0.07 & 0.054 & 1.4 & 0.010 & $<0.01$ & 1.3 & $<0.05$ & $<0.01$ \\
\hline $\begin{array}{l}\text { Median } \\
\text { Value }\end{array}$ & $\begin{array}{l}0.076 \\
\pm 0.05\end{array}$ & $\leq 0.64$ & $<0.25$ & $\begin{array}{r}2.4 \\
\pm 2.5\end{array}$ & $<0.015$ & $\leq 0.09$ & $\begin{array}{r}4.2 \\
\pm 5.4\end{array}$ & $<0.25$ & $<0.035$ \\
\hline $\begin{array}{l}\text { TCLP } \\
\text { Criterion }^{d}\end{array}$ & 0.20 & 5.00 & 5.00 & 100 & 1.0 & 5.0 & NA & 1.0 & 5.0 \\
\hline $\begin{array}{l}\text { UTS } \\
\text { Criterion }\end{array}$ & 0.025 & 0.37 & 5.00 & 7.60 & 0.19 & 0.86 & 5.0 & 0.16 & 0.30 \\
\hline
\end{tabular}

LMES Analytical Laboratory Information System Sample Identification Number (data archive).

${ }^{b}$ Atomic Absorption Spectroscopy (EPA Method 7470).

Inductively Coupled Plasma Spectroscopy (EPA Method 6010).

${ }^{d}$ Toxicity Characteristic Leaching Procedure (40 CFR 261.24).

Universal Treatment Standard for hazardous waste: TCLP extract (nonwastewater) (60 CFR 264). 
consistent with industry reports. Data presented by Meyer (1992) indicates that the total mercury content in the glass/phosphor component of typical 4-foot long $\times$ 1.5-inch diameter cool-white fluorescent lamps (F40T12) may be in the range of $\sim 100-180 \mu \mathrm{g} / \mathrm{g}$, with the higher value being associated with older lamps. It is probable that some mercury is lost from the crushed lamp inventory by volatization or particulate entrainment during the crushing operation (which is conducted at reduced pressure, with off-gas processing through an activated carbon canister) (EPA 1994).

\subsection{Investigations in Support of the Proposed Treatment Flowsheet}

\section{Microscopic Examination of Glass/Phosphor}

A used (nonwaste) F40T12 lamp was broken to evaluate the association between mercury and phosphor on the glass envelope. In agreement with manufacturers' data, the preponderance of phosphor particles ranged from approximately 2-20 $\mu \mathrm{m}$ in greatest dimensions. Mercury-rich phases were identified in association with the phosphor particulate phase; in general, these mercury-rich phases appear as small spherical particles, possibly as liquid mercury droplets. A band of dark discoloration was noted on the glass near the electrode filament ends; this band was notably emriched in small lead-containing particles and was likely the result of volatilization from the leaded glass components during service.

\section{Solubilization of Mercury}

Gates and co-workers (1995) demonstrated that a $6 \%$ solution of $\mathrm{NaOCl}$, adjusted to $\mathrm{pH} \sim 2$, was highly effective in solubilizing elemental mercury. Hypochlorous acid $(\mathrm{HOCl})\left(\mathrm{pK}_{\mathrm{a}}=7.48\right)$ is a strong oxidant and is the predominant hypochlorite species in acidic solution. We tested the effect of three variables (solution $\mathrm{pH}, \mathrm{NaCl}$ concentration, and hypochlorite concentration) on the solubilization of liquid mercury. Of these, the hypochlorite concentration was the most significant factor (more mercury was solubilized with higher concentration of hypochlorite). At a given level of hypochlorite, somewhat greater quantities of mercury were solubilized at lower $\mathrm{pH}$ values (i.e., 4 versus 7) and at moderate concentrations of $\mathrm{NaCl}$ (to form the stable complex $\mathrm{HgCl}_{4}{ }^{2-}$ ion; Pedroso et al, 1994). At $\mathrm{pH}$ values much less than 4, the formation of chlorine gas is favored, which may be lost due to its volatility (Pedroso et al. 1994), and at $\mathrm{pH}$ values much greater than 7 , the hydrolysis of mercury can occur with loss due to precipitation. The mercury leachant composition selected for further testing contained $\sim 0.5$ weight percent (wt \%) $\mathrm{NaOCl}$ and $75 \mathrm{~g} / \mathrm{L} \mathrm{NaCl}$, adjusted to an initial $\mathrm{pH}$ value of 4 . 
Hypochlorous acid should also be effective in solubilizing certain radiological contaminants, if they are actually present in the waste stream. Gates et al. (1995A) show that neither the hypochlorite/chloride nor iodine/iodide extraction systems solubilize appreciable ceric oxide $\left(\mathrm{CeO}_{2}\right)$ (a nonradiological surrogate for insoluble uranium oxide; see also Stockdale et al., 1994); however, these systems should readily solubilize uranium contamination if it is present in the form of uranyl compounds. The other radionuclide of interest that could be present in waste at the $\mathrm{K}-25$ Site is ${ }^{99} \mathrm{Tc}$ - a weak beta emitter-that would be readily solubilized as the pertechnetate ion in oxic media (Pourbaix, 1974). Technetium-99 in packaged debris waste cannot be easily detected by nondestructive assay (NDA) - unlike uranium and its decay daughters, which have penetrating characteristic gamma emission. Therefore, extraction of ${ }^{99} \mathrm{Tc}$ will aid in the certification of solid debris waste as "no radioactivity added" by NDA survey.

\section{Mercury Recovery from Hypochlorite/Chloride Leachate: Batch Equilibrium Sorption Studies}

Table 2 (from Cooney et al., 1992) summarizes typical results attainable for treatment of mercury salts in plating wastewaters. In initial screening tests we examined the utility of several sorbent media for removal of soluble mercuric ions from aqueous solution (mercuric chloride in distilled water). In this solution traditional mercury sorption media, such as sulfur-impregnated granular activated carbon (Mersorb) and ion-exchange resin (Duolite) (cf. Table 2) were less effective than metal wool (copper and steel); see Figure 3. In Figure 4, we compare efficiencies for trace soluble mercury, in both de-ionized water (cf. Figure 3) and in 7.5 wt \% salt solution, using two of the more effective media (steel wool and Duolite resin). In this testing, both media appeared comparably effective for removal of mercury in salt solution; however, the steel wool reagent was selected for use in dynamic flow testing because it is less expensive.

Copper and steel wools and steel wool with a thin layer of galvanically-deposited copper (see Equation 2) were comparable in their effectiveness (Figure 5) with each material removing $3.5-4 \mathrm{~g}$ of $\mathrm{Hg}$ per $\mathrm{g}$ of metal at equilibrium from concentrated solution ( $\mathrm{cf}$, molecular weight ratio, $\mathrm{Hg} / \mathrm{Fe}=3.6$ ). (Copper flashed on steel wool may decrease the loss of steel substrate due to parasitic corrosion). The electrochemical displacement and precipitation of a metal from solution by a metal higher in the electromotive series (see Table 3 ) is referred to as "cementation" and iron metal is most often used as the sacrificial anode (Cooney et al., 1992). Zero-valent iron can also spontaneously reduce mercurous and mercuric ions to elemental mercury (Equations 3 and 4).

$$
\mathrm{Cu}^{2+}+\mathrm{Fe}=\mathrm{Cu}+\mathrm{Fe}^{2+} \quad \mathrm{E}^{0}(\text { cell })=+0.789 \mathrm{~V}
$$




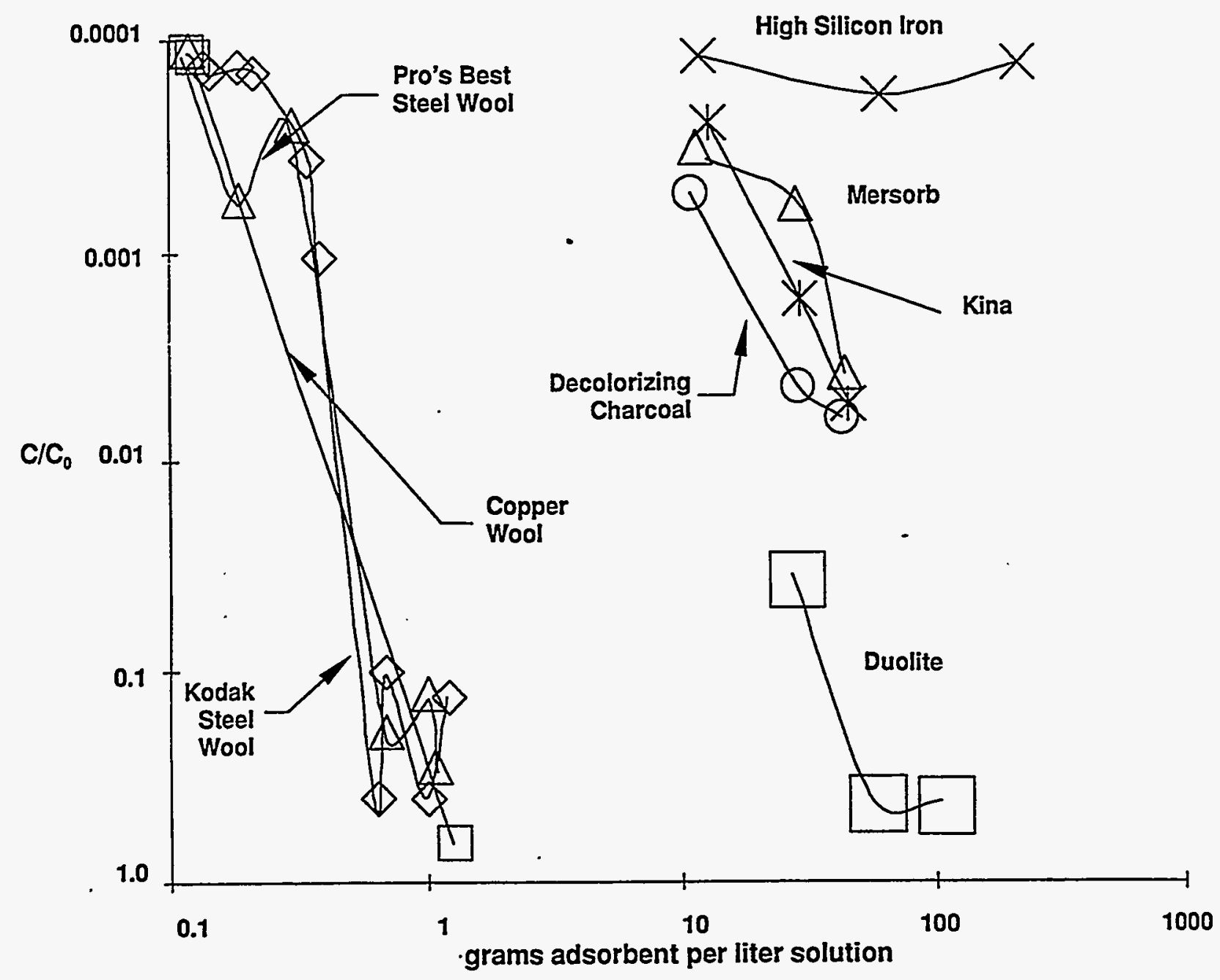

Figure 3. Removal of soluble mercury (as $\mathrm{HgCl}_{2}$ in distilled water) with use of various media. 



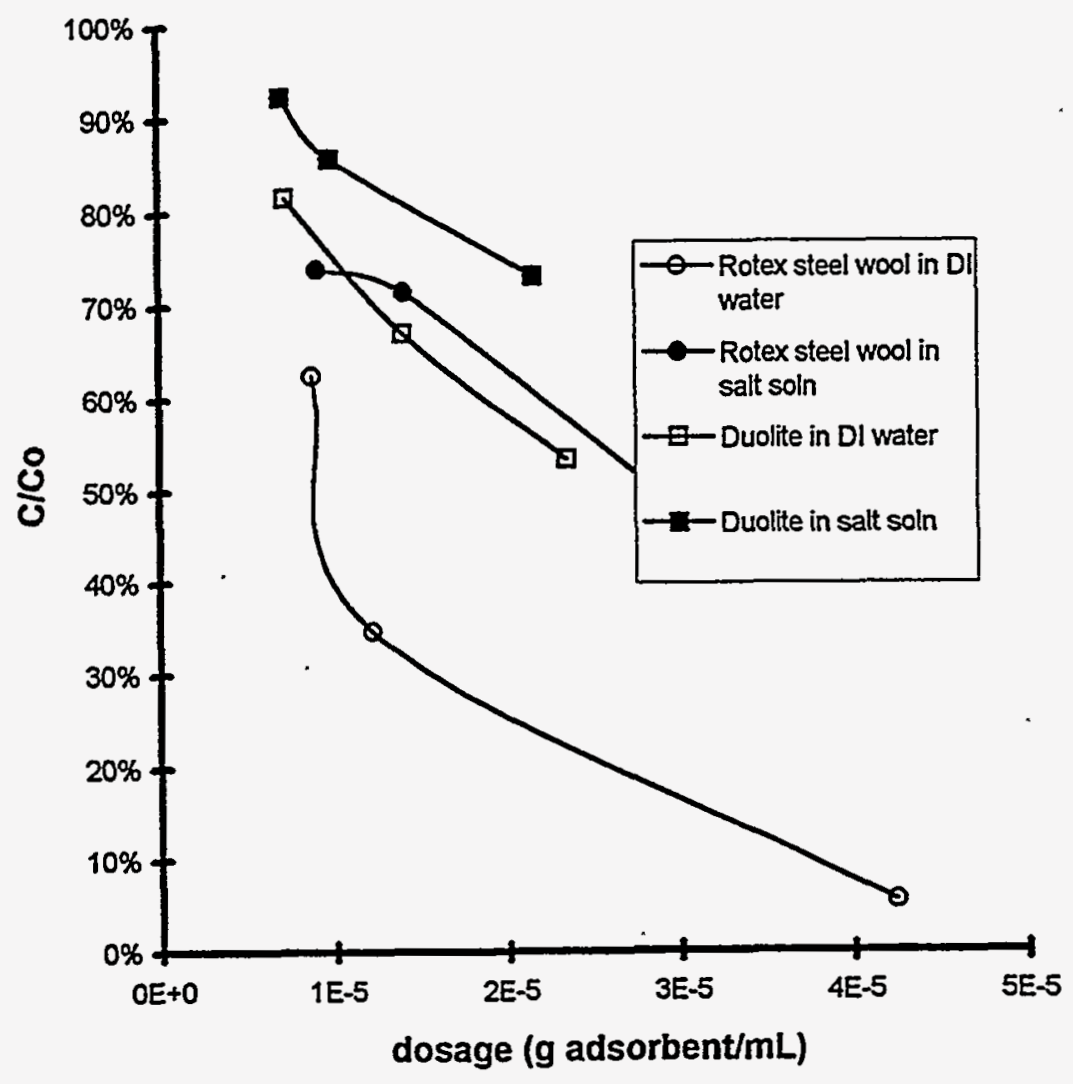

Equilibrium Concentration vs. Dosage for Sorption of $\mathrm{Hg}(\mathrm{Co}=10 \mathrm{ppm})$ in DI Water (cf. 7.5 wt\% $\mathrm{NaCl}$ soln)

Fig. 4. Comparison of Rotex steel wool and Duolite GT-73 resin for the removal of trace soluble mercury $\left(C_{0}=10 \mathrm{mg} / \mathrm{L}\right)$ from de-ionized water and from $7.5 \mathrm{wt} \%$ sodium chloride solution. (Sorbent dosage reported as dry-weight equivalent.) 


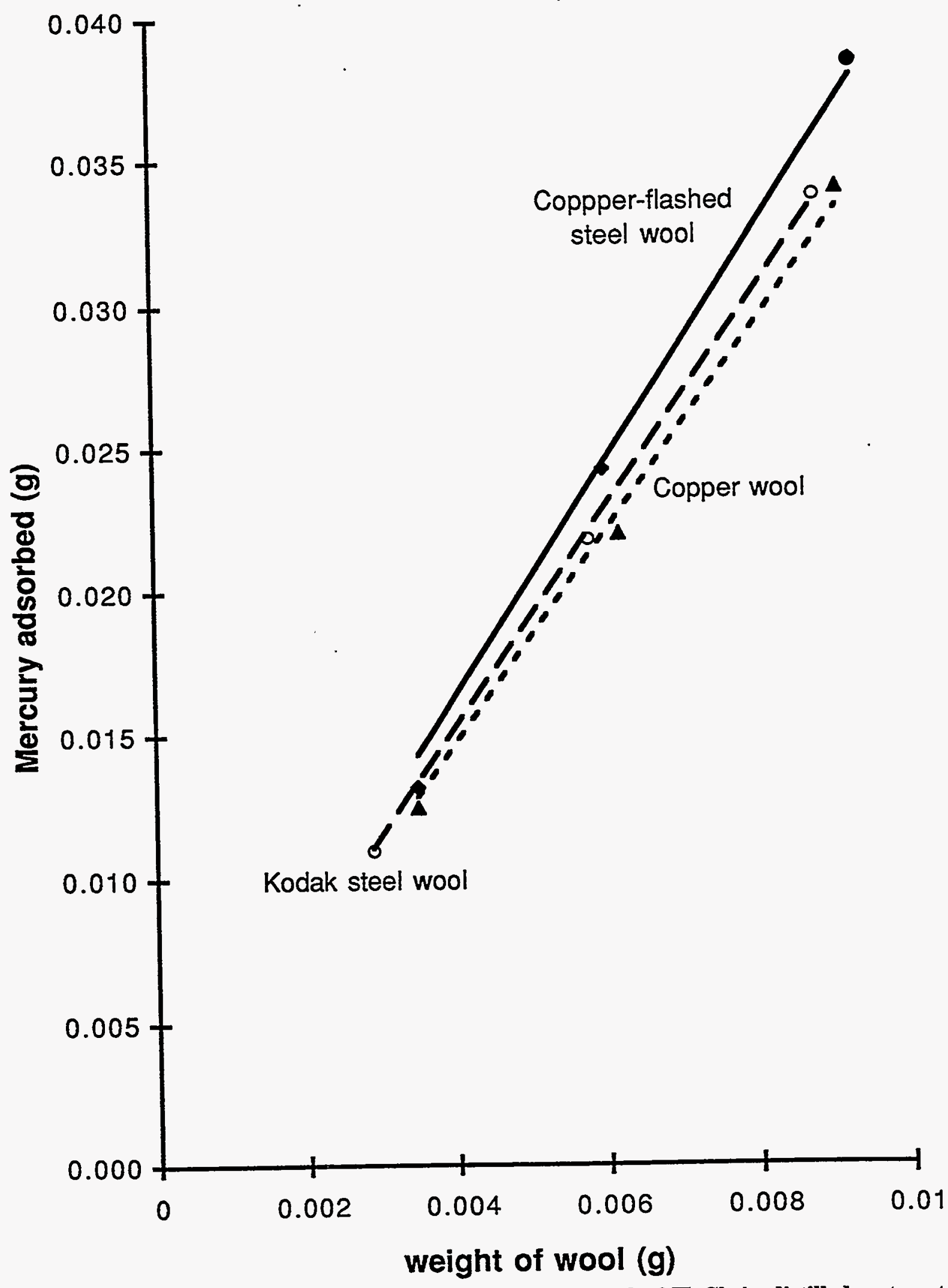
equilibrium.

Figure 5. Comparison of metal wool products for removal of $\mathrm{HgCl}_{2}$ in distilled water at 


\section{TABLE 2. TREATMENT TECHNOLOGY EFFECTIVENESS FOR MERCURY IN PLATING WASTEWATER}

(From Cooney et al., 1992)

\begin{tabular}{lc}
\hline \multicolumn{1}{c}{ Technology } & $\begin{array}{c}\text { Lower Limit of Treatment Capability } \\
\text { (mg/L) }\end{array}$ \\
\hline Sulfide Precipitation & $10-20$ \\
Ion Exchange & $1-5$ \\
Alum Coprecipitation & $1-10$ \\
Iron Coprecipitation & $0.5-5$ \\
Activated Carbon Adsorption & \\
$\quad$ High Initial Mercury & 20 \\
$\quad$ Moderate Initial Mercury & 2 \\
Low Initial Mercury & 0.25 \\
\hline
\end{tabular}

TABLE 3. SELECTED STANDARD ELECTRODE POTENTIALS FOR ACIDIC AQUEOUS SOLUTIONS AT $25^{\circ} \mathrm{C}^{*}$

\begin{tabular}{lll}
\hline Couple & Electrode Reaction & $\mathrm{E}^{0}, \mathrm{~V}$ \\
\hline $\mathrm{Al}^{3+} / \mathrm{Al}$ & $\mathrm{Al}^{3+}+3 \mathrm{e}^{-}=\mathrm{Al}$ & -1.662 \\
$\mathrm{Zn}^{2+} / \mathrm{Zn}$ & $\mathrm{Zn}^{2+}+2 \mathrm{e}^{-}=\mathrm{Zn}$ & -0.762 \\
$\mathrm{Fe}^{2+} / \mathrm{Fe}$ & $\mathrm{Fe}^{2+}+2 \mathrm{e}^{-}=\mathrm{Fe}$ & -0.447 \\
$\mathrm{~Pb}^{2+} / \mathrm{Pb}$ & $\mathrm{Pb}^{2+}+2 \mathrm{e}^{-}=\mathrm{Pb}$ & -0.126 \\
$\mathrm{Cu}^{2+} / \mathrm{Cu}$ & $\mathrm{Cu}^{2+}+2 \mathrm{e}^{-}=\mathrm{Cu}$ & +0.342 \\
$\mathrm{Hg}_{2}^{2+} / \mathrm{Hg}$ & $\mathrm{Hg}^{2+}+2 \mathrm{e}^{-}=2 \mathrm{Hg}$ & +0.797 \\
$\mathrm{Ag}^{+} / \mathrm{Ag}$ & $\mathrm{Ag}^{+}+\mathrm{e}^{-}=\mathrm{Ag}$ & +0.800 \\
$\mathrm{Hg}^{2+} / \mathrm{Hg}$ & $\mathrm{Hg}^{2+}+2 \mathrm{e}^{-}=\mathrm{Hg}$ & +0.851 \\
\hline
\end{tabular}

*Compiled from CRC Handbook of Chemistry and Physics, 68 th Ed. 


$$
\begin{array}{ll}
\mathrm{Hg}^{2+}+\mathrm{Fe}=\mathrm{Hg}+\mathrm{Fe}^{2+} & \mathrm{E}^{0}(\text { cell })=+1.298 \mathrm{~V} \\
\mathrm{Hg}_{2}{ }^{2+}+\mathrm{Fe}=2 \mathrm{Hg}+\mathrm{Fe}^{2+} & \mathrm{E}^{0}(\text { cell })=+1.244 \mathrm{~V}
\end{array}
$$

(Standard cell potentials are computed from the tabulated data presented in Table 3. By sign convention, a positive cell potential represents a thermodynamically favored reaction).

Rockandel (1992) reports that inexpensive ground steel scrap is an effective cementation medium for mercury recovery and that the optimum cementation $\mathrm{pH}$ is in the range of $2-4$. This cementation reaction produces relatively high concentrations of ferrous iron [Fe(II)], which is subsequently oxidized by exposure to air to form ferric ion [Fe(III)]. Recently, Grau and Bisang (1995) have also shown that iron felt rapidly removes soluble mercury from solutions containing chloride ion. Other active zero-valent metals [including copper (Tyson 1993) and zinc (Pedroso et al., 1994)] can be used as the cementation agent for mercury recovery, but these metals are more expensive and produce replacement salts that are generally more toxic than the corresponding iron salts in aqueous systems (Luckey et al., 1975).

Granulated corrosion-resistant ASTM A-518 high-silicon steel was not effective for removal of soluble mercury, suggesting that galvanic reduction of mercuric ion is coupled to the oxidation of an iron metal substrate.

\section{Mercury Recoverv: Packed-Column Breakthrough Studies}

Based upon the batch equilibrium sorption studies described above, steel wool was selected for column breakthrough testing. This material was removed from an Eastman Kodak Chemical Recovery Cartridge II (Fig. 6); this canister, used for recovery of silver from photographic waste solutions, is prepackaged to contain 3.4 $\mathrm{kg}$ steel in a nominal 20-L active volume, for a nominal packing density of $\sim 0.17 \mathrm{~g} \mathrm{steel} / \mathrm{cm}^{3}$. With a strand diameter of $93 \mu \mathrm{m}$, the nominal surface area for this material is $\sim 0.006 \mathrm{~m}^{3} / \mathrm{g}$. Vendor-supplied literature (Kodak Technical Publication J-9) indicates that optimum cementation with silver from waste solution occurs under slightly acidic conditions (pH4-6.5), which allows for a controlled rate of steel corrosion concurrent with reduction of pollutant metal ions. The insoluble reduced form of the metal of interest remains in the canister for later reclamation. Assuming a density for steel of $\sim 7.7 \mathrm{~g} / \mathrm{cm}^{3}$ suggests that the packed canister contains $~ 98 \%$ void volume, which is ample allowance for the volumetric increase that occurs as iron corrodes into iron oxides. Operation of the unit with waste feed solution at $\mathrm{pH}$ values between 4 and 6 minimizes the deposition of iron hydroxide sludge in the active treatment zone. At $\mathrm{pH}$ values less than 4 , steel corrosion may be excessive, limiting the effective operational lifetime fo the treatment canister. At $\mathrm{pH}$ values greater than $\sim 9.5$, the steel surface becomes passivated (Pourbaix 1974) and is no longer effective as a reducing agent; this condition is illustrated 


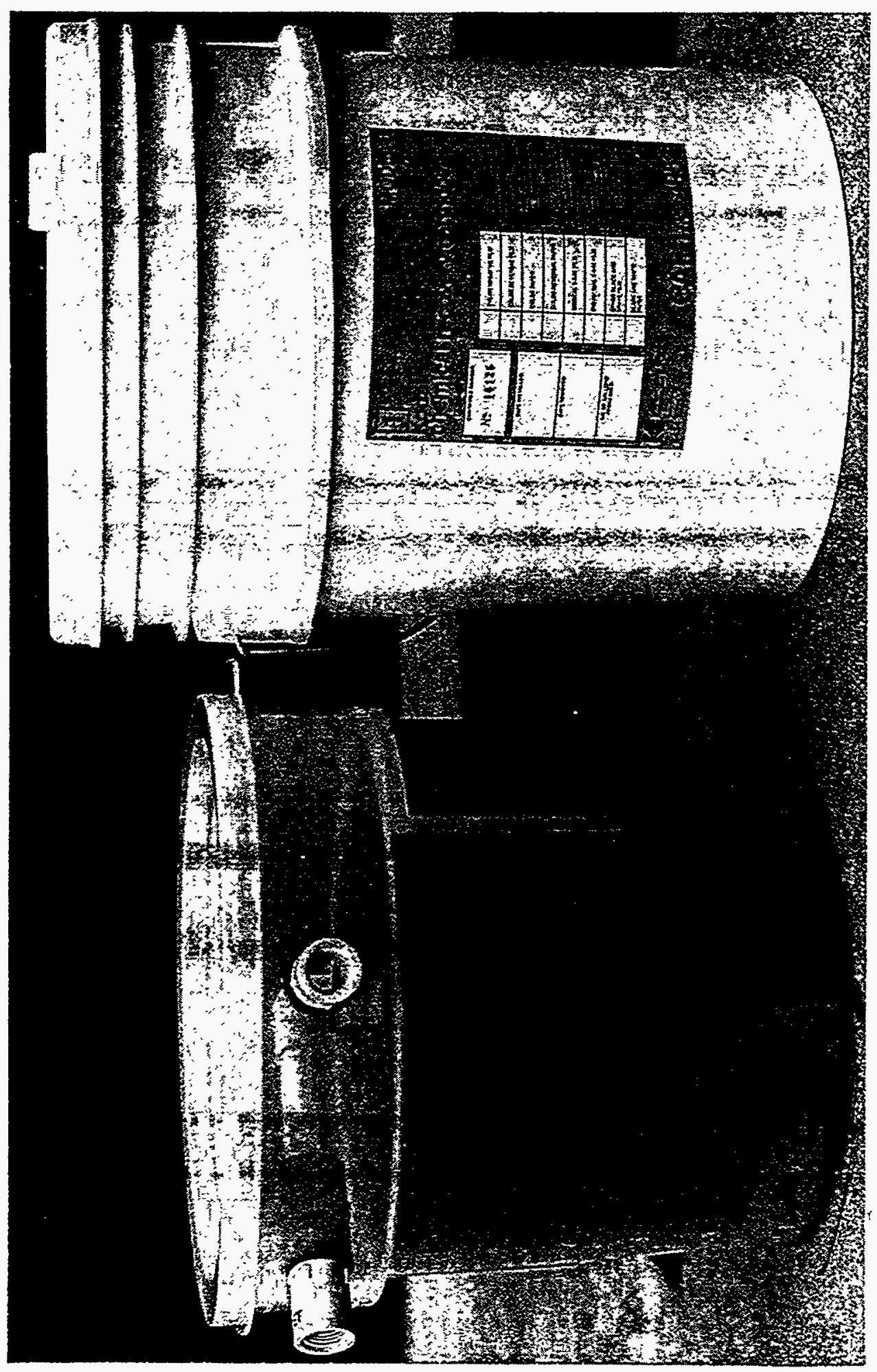

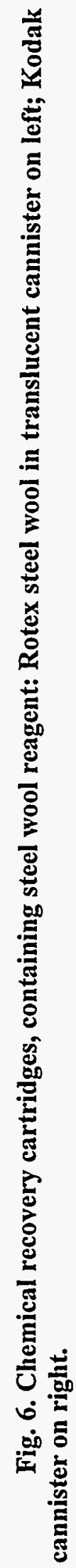




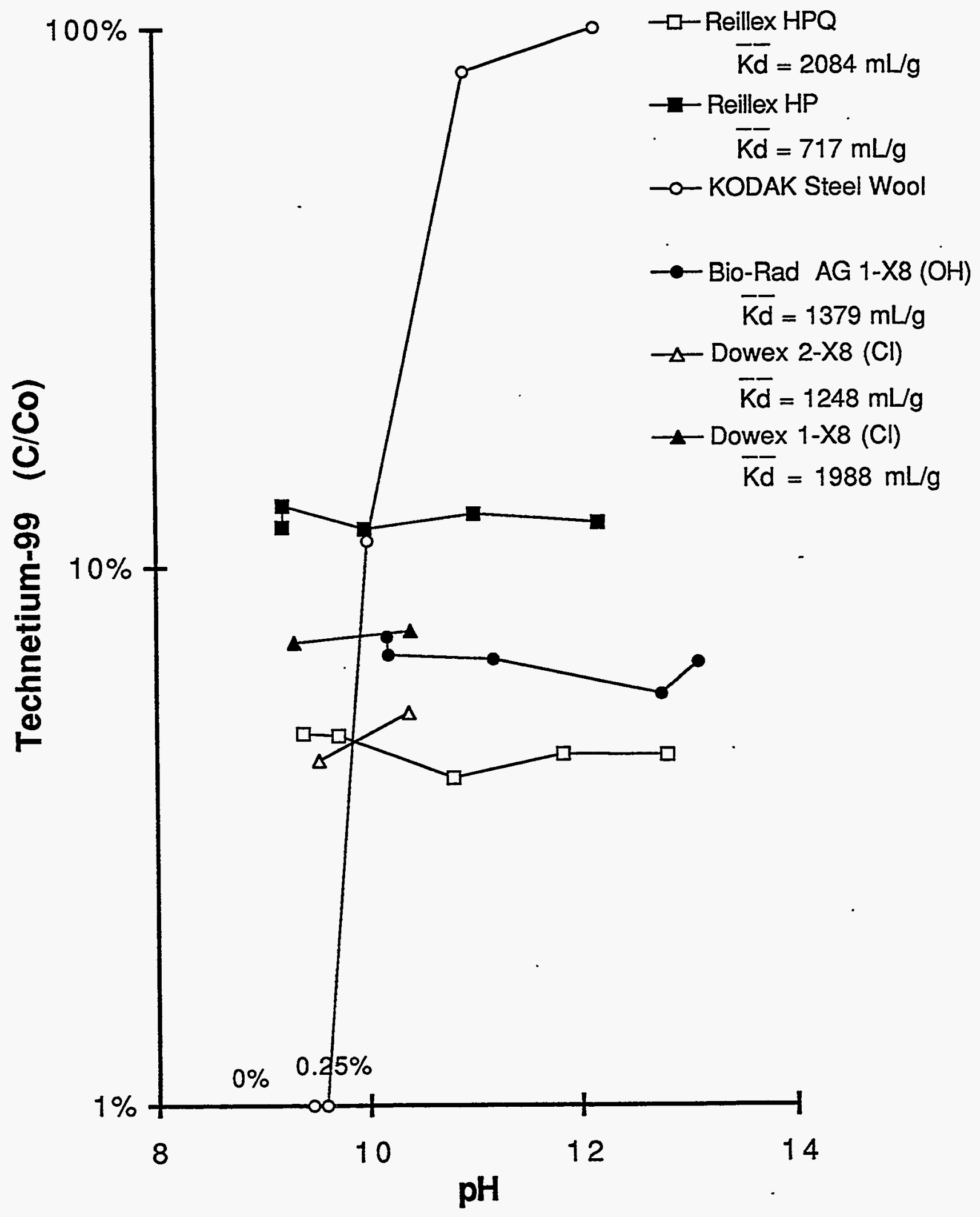

Figure 7. Removal of soluble technetium-99 from carbonate solution by zero-valent iron (Kodak steel wool) and selected anion-exchange resins as a function of equilibrium solution $\mathrm{pH}$ value. (0.01 $\mathrm{g}$ as received sorbent/mL simulated Oak Ridge National Laboratory newly-generated low-level liquid waste process waterwater). From Bostick et al., 1995b. 
in Figure 7 for the reduction of the radionuclide technetium-99 (zero-valent iron reduces soluble $\mathrm{Tc}$ (VII), as pertechnetate ion, to insoluble Tc(IV) oxyhydroxide; Del Cul and Bostick, 1995; Bostick et al., 1995b). Thus,

${ }^{99} \mathrm{Tc}$ (if present in the leachate) would also be removed by treatment with steel wool. Recent work by Cantrell et al. (1995) demonstrates that metallic iron is effective for removal of botb uranyl ion $\left(\mathrm{UO}_{2}{ }^{2+}\right)$ and pertechnetate ion.

\section{Packed-Column Breakthrough Studies}

For laboratory-scale studies, Kodak steel wool was packed into glass columns, and radiologically-traced mercuric chloride solution was fed to the column by upflow. The initial concentration, $\mathrm{C}_{0}$, for total $\mathrm{Hg}$ was $\sim 3,000 \mathrm{mg} / \mathrm{L}$ in $7.5 \mathrm{wt} \% \mathrm{NaCl}$ solution, $\mathrm{pH} \sim 6$. Table 4 summarizes the experimental conditions and performance for incipient breakthroughs (defined here as $\mathrm{C} / \mathrm{C}_{0} \sim 0.01$ ). Breakthrough data are plotted in Figure 8. There appears to be an optimal range for liquid flow through the steel wool. At low liquid flow rates, gases formed by the corrosion of iron, or entrained air, can coalesce, forming bubbles entrapped in the metal mesh; this prevents solution from wetting the metal surface, creating channelized flow and decreased treatment efficiency. At sufficiently high flow rates, small droplets of liquid mercury reduction products may be transported from the column before they can coalesce.

Table 4. SUMMARY OF CONDITIONS FOR PACKED-COLUMN BREAKTHROUGH STUDIES USING KODAK STEEL WOOL

\begin{tabular}{|c|c|c|c|}
\hline & Run 1 & Run 2 & Run 3 \\
\hline Initial Active Zone Dimensions & $\begin{array}{l}5.25 \mathrm{~cm}^{3}[1.0 \mathrm{~cm}(\mathrm{D}) \\
\times 6.83 \mathrm{~cm}(\mathrm{~L})]\end{array}$ & $\begin{array}{l}6.32 \mathrm{~cm}^{3}[1.0 \mathrm{~cm}(\mathrm{D}) \times \\
8.26 \mathrm{~cm}(\mathrm{~L})]\end{array}$ & $\begin{array}{l}2.75 \mathrm{~cm}^{3}[0.7 \mathrm{~cm}(\mathrm{D}) \times \\
7.14 \mathrm{~cm}(\mathrm{~L})]\end{array}$ \\
\hline Mass of Steel Wool (g) & 4.89 & 4.89 & 2.00 \\
\hline 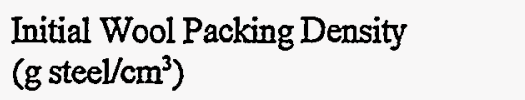 & 0.93 & 0.78 & 0.73 \\
\hline Solution Feed Rate & $\begin{array}{l}0.41 \mathrm{~mL} / \mathrm{min} \\
\left(0.13 \mathrm{gpm} / \mathrm{ft}^{2}\right)^{a}\end{array}$ & $\begin{array}{l}0.91 \mathrm{~mL} / \min \\
\left(0.29 \mathrm{gpm} / \mathrm{ft}^{2}\right)^{a}\end{array}$ & $\begin{array}{l}1.1 \mathrm{~mL} / \mathrm{min} \\
\left(0.67 \mathrm{gpm} / \mathrm{ft}^{2}\right)^{a}\end{array}$ \\
\hline Nominal Residence Time (minute) & 12.8 & 6.9 & 2.6 \\
\hline $\begin{array}{l}\text { Loading of Mercury on Steel at } \\
\text { Incipient Breakthrough } \\
(\mathrm{g} \mathrm{Hg} / \mathrm{g} \mathrm{Fe})^{b}\end{array}$ & $\sim 1.25$ & $>1.70$ & $\sim 1.23$ \\
\hline Total Experimental Run Time (days) & $\sim 3.2$ & $\sim 2.0$ & $\sim 0.6$ \\
\hline
\end{tabular}





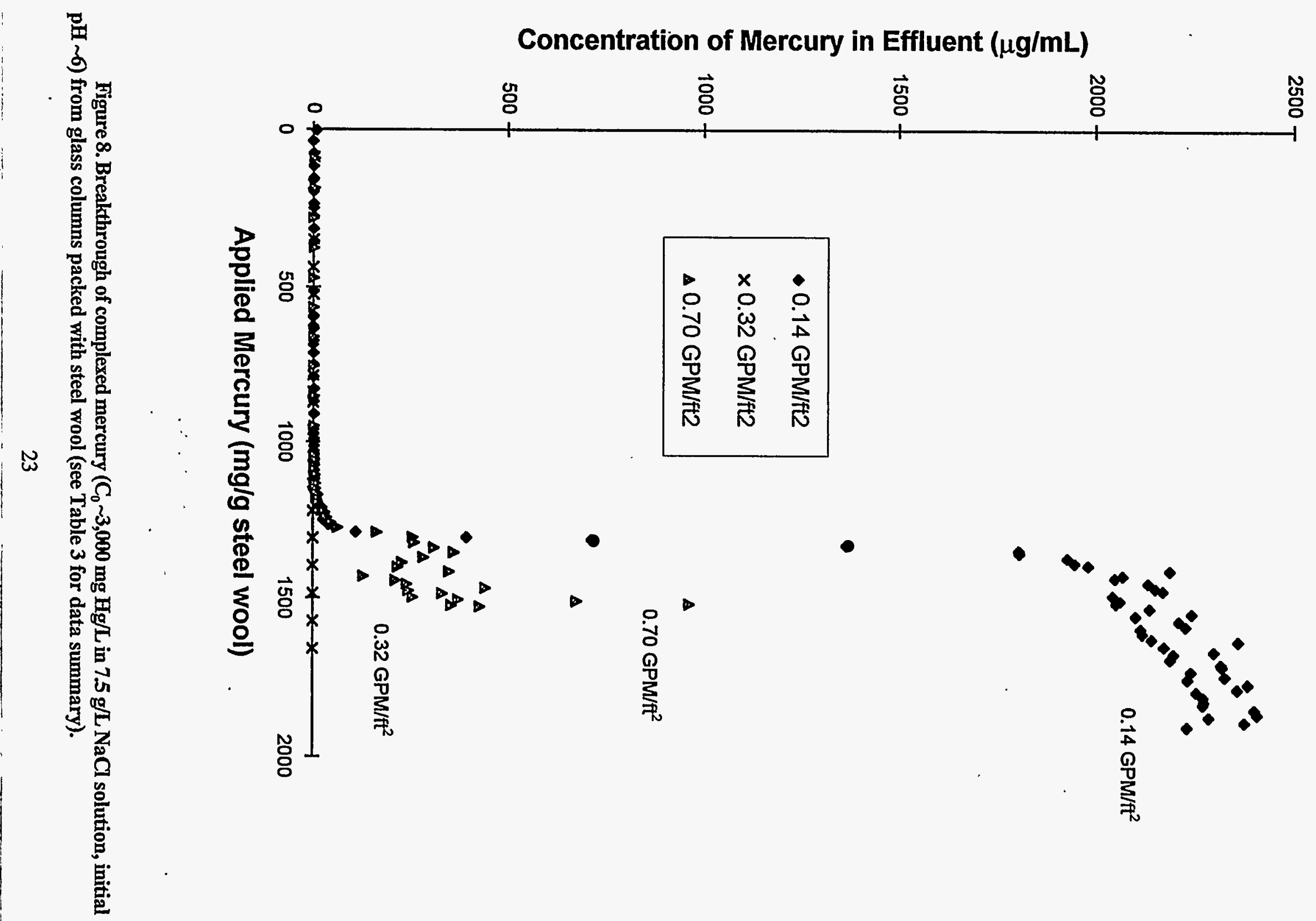


As noted from Table 4 and Figure 8, at favorable dynamic flow rates, it is possible to remove a greater mass of mercury than the original mass of steel present in the active zone (>1.2 $\mathrm{g} \mathrm{Hg}$ per $\mathrm{g}$ Iron) before appreciable breakthrough of soluble mercury occurs. Thus, in principle, a single Kodak canister ( $\sim 5$-gal capacity), containing $3.4 \mathrm{~kg}$ steel, could remove $\sim 4.1 \mathrm{~kg} \mathrm{Hg}$ under optimal conditions before an appreciable breakthrough. This would correspond to the total mercury content of $\sim 120,00048$-inch fluorescent lamps (or $>200$ 55-gallon drums of crushed lamps). In practice, cementation reactions with contaminant metal ions must compete with the consumption of steel due to simple corrosion mechanisms. For the incipient breakthrough data presented in Table 4, with a high concentration of mercury in the feed solution, $\sim 1 / 3$ of the initial amount of steel had been consumed by reaction with mercury (i.e., a yield of $>1.2 \mathrm{~g}-\mathrm{Hg} / \mathrm{g}-\mathrm{Fe}$ at $\mathrm{C} / \mathrm{C}_{0}=0.01$, versus $\sim 3.6 \mathrm{~g}-\mathrm{Hg} / \mathrm{g}-\mathrm{Fe}$ at equilibrium), with most of the balance of the initial mass of steel being consumed by simple corrosion in the salt water medium.

A small packed column of steel wool was tested using untraced (nonradiological) mercury to facilitate examination of the column contents after a breakthrough of soluble mercury. Void spaces in the corroded steel fiber "mush" were observed to contain beads of elemental mercury (Figure 9). By X-ray diffraction, some insoluble calomel $\left(\mathrm{Hg}_{2} \mathrm{Cl}_{2}\right)$ was also detected. Iron phases in the mush were predominantly magnetite $\left(\mathrm{Fe}_{3} \mathrm{O}_{4}\right)$, with hematite $\left(\mathrm{Fe}_{2} \mathrm{O}_{3}\right)$ and elemental iron also present.

At moderate flow rates, mercury removal continued to be efficient as long as some steel metal was present in the column. Recently, we have obtained packed steel wool canisters in custom-fabricated translucent plastic containers (Rotex Silver Recovery Co.), which will facilitate visual estimation of a recovery unit's operational lifetime. From Table 4, the consumption rate for steel wool before an appreciable breakthrough of soluble mercury in a corrosive salt solution was $\sim 1.5-3.3 \mathrm{~g} /$ day.

\section{Steel Wool Canister Effluent Polishing}

The redox activity of the steel wool column was also evident from the various color phases observed in the glass column and translucent tubing that lead to the fraction collector. The effluent immediately downstream from the packed column had a greenish tint, suggestive of ferrous chloride, and further downstream, the effluent became orange-brown, suggestive of oxidized ferric hydroxide. The pooled, post-breakthrough effluent equilibriated with air contained predominantly soluble or colloidal ferric and mercuric ions. Filtration of the airequilibriated effluent through $0.8-$ and $0.2-\mu \mathrm{m}$ filter media did not remove appreciable mercury $\left(C / C_{0}=0.96\right.$ and 

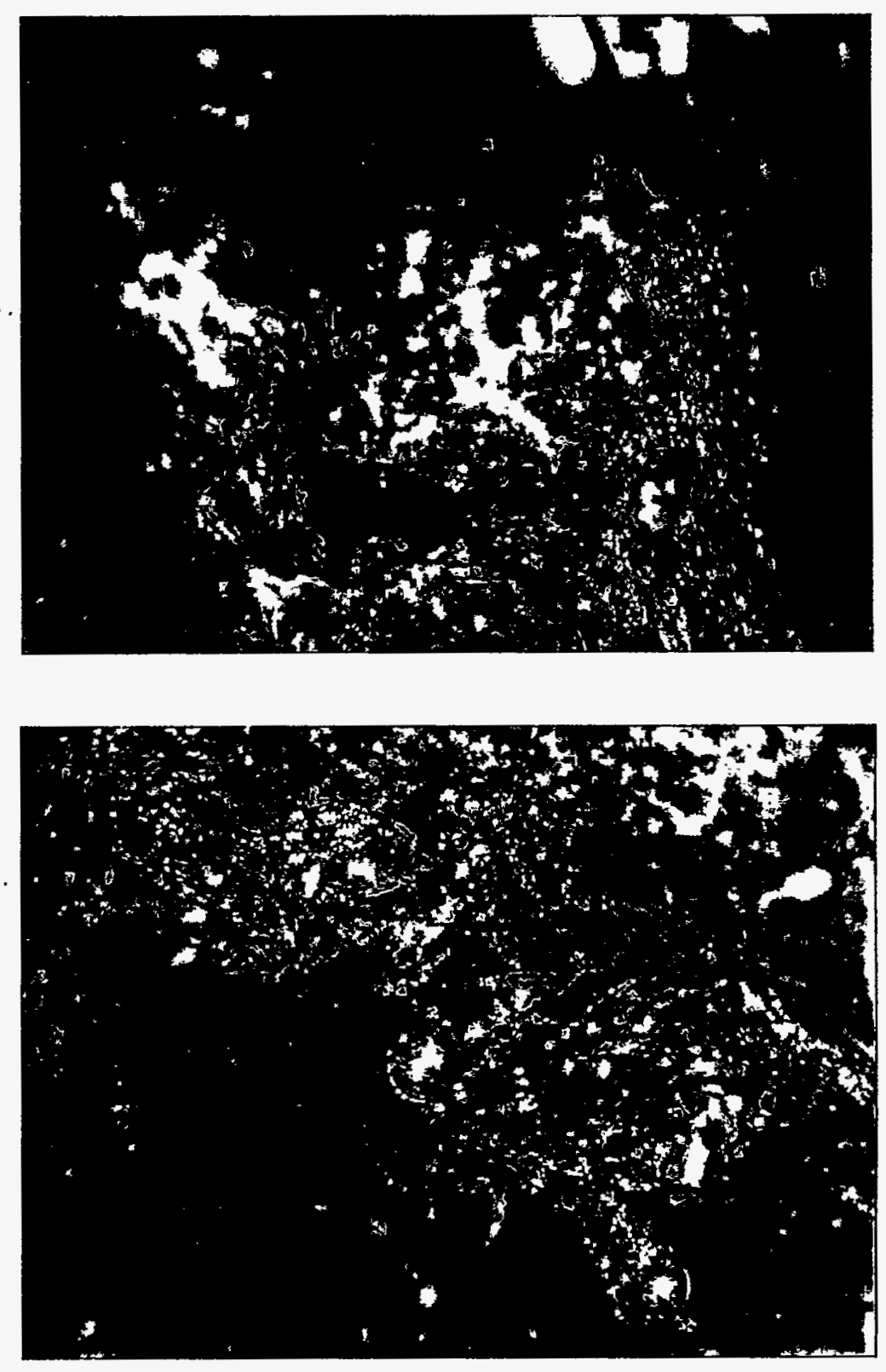

Figure 9. Beads of elemental mercury after breakthrough in a packed column of steel wool. 
0.93, respectively), although the effluent was progressively decolorized (attributed to the removal of colloidal iron or other material in suspension).

As discussed earlier, the on-site wastewater treatment facility uses iron co-precipitation as the primary treatment to remove soluble toxic metals and radionuclides (Bostick et al., 1992, 1995a). The effluent from the lamp leaching projects would be diluted with a large volume of other wastes (predominately saline scrubber blowdown from a mixed waste incinerator). To test for mercury removal by iron coprecipitation treatment, we used a composite column effluent which included post-breakthrough samples; this sample contained $\sim 70 \mathrm{mg} / \mathrm{L}$ soluble mercury at an initial $\mathrm{pH} \sim 6.6$. An aliquot was acidified (to $\mathrm{pH} \sim 3$ ), and $50 \mathrm{mg} / \mathrm{L}$ of $\mathrm{Fe}$ (III) was added (as ferric sulfate). The solution was readjusted to $\mathrm{pH} \sim 8.6$, and flocculated with $\sim 15 \mathrm{mg} / \mathrm{L}$ Betz 1138 polymer. The clarified supemate was filtered before counting; removal efficiency for mercury was $\sim 76 \%$ (i.e., $C / \mathrm{C}_{0} \sim 0.24$, with a soluble residual of $\sim 17 \mathrm{mg} / \mathrm{L})$. A 10-fold dilution of pooled effluent $\left(\mathrm{C}_{0} \sim 6.6 \mathrm{mg} / \mathrm{L}\right)$ was also treated by coprecipitation, yielding a removal efficiency of $\sim 59 \%$ (soluble residual of $\sim 2.7 \mathrm{mg} / \mathrm{L}$ ) Thus, as noted in Table

2, coprecipitation will be an efficient wastewater "polishing" step for the liquid effluent from the sorption unit operation of the proposed lamp leaching process.

\subsection{RCRA Treatability Studies in Support of Proposed Treatment Flowsheet}

Examination of the crushed lamps revealed two distinct types of materials: (1) shards of broken glass envelope with phosphor attached, and (2) aluminum endcap assemblies with leaded glass and filaments attached. These components were tested by the TCLP, both separately and in a mixture representing the proportionate mass ratios found in intact lamps (i.e., $\sim 90 \%$ glass/phosphor and $\sim 10 \%$ endcap assemblies; Foust, 1994). Testing was performed for the original (untreated) material and material that had been treated by preleaching with a solution containing $-0.5 \mathrm{wt} \% \mathrm{NaOCl}$ and $75 \mathrm{~g} / \mathrm{L} \mathrm{NaCl}$, adjusted to an initial $\mathrm{pH}$ value of 4 . Liquid and solid phases were contacted in sealed jars placed on a rolling mill for 6 hours. Solids were contacted first with a bleach/salt "wash" solution. Phases were then separated by either filtration or decantation. Next, distilled water was added to the solid phase as a rinse solution, before again contacting phases by mixing on a rolling mill followed by a final phase separation to recover the treated solids.

\section{Testing with Glass/Phosphor Component}

As noted previously, the glass envelope and its associated phosphor component should have the greatest proportion of mercury in the crushed lamps. Using untreated glass/phosphor from the inventoried crushed lamps, 
the concentration of mercury in the TCLP leachate averaged $(0.14 \pm 0.01) \mathrm{mg} / \mathrm{L}$.

In the first series of treatment evaluation, $100 \mathrm{~g}$ of glass/phosphor shards were initially contacted with $\sim 860 \mathrm{~g}$ of $\mathrm{bleach} / \mathrm{salt}$ solution, resulting in a liquid/solid (L/S) mass ratio of $\sim 8.6$. The glass and leach solution were contacted by rolling the mixture in a sealed cylindrical 1-gallon jar for 6 hours. The phases were separated by coarse filtration (hardened Whatman 54 paper, nominal 20-25 mm-pore), backed by a $1 \mathrm{~mm}$-pore membrane filter medium. The solids were returned to the jar, together with $1000 \mathrm{~mL}$ of distilled water rinse solution (L/S $=10$ ), mixed by rolling for $2-4$ hours, and then refiltered. Duplicate samples of washed solids were submitted for TCLP extraction (see Table 5), both yielded no detectable mercury in the TCLP leachate $(<0.001 \mathrm{mg} / \mathrm{L})$.

\section{Table 5. TCLP LEACHATE TESTING FOR CRUSHED FLUORESCENT LAMP COMPONENTS}

\begin{tabular}{|c|c|c|}
\hline \multirow[b]{2}{*}{ Sample Description } & \multicolumn{2}{|c|}{ Metal in TCLP Extract (mg/L) } \\
\hline & Mercury (Hg) & Lead $(\mathrm{Pb})$ \\
\hline \multicolumn{3}{|l|}{ Glass/Phosphor Component } \\
\hline Untreated & 0.14 & 0.12 \\
\hline Treated $^{a}:$ Series $1(\mathrm{~L} / \mathrm{S} \sim 8.6)^{b}$ & $<0.001$ & 0.17 \\
\hline Treated ${ }^{a}:$ Series $2(\mathrm{~L} / \mathrm{S} \sim 2.0)^{b}$ & $\leq 0.0015$ & 0.19 \\
\hline \multicolumn{3}{|l|}{ Endcap/Leaded Glass Component } \\
\hline Untreated & 0.023 & 0.016 \\
\hline Treated $^{a}(\mathrm{~L} / \mathrm{S} \sim 7.8)^{b}$ & 0.012 & 0.011 \\
\hline \multicolumn{3}{|l|}{ Glass/Phosphor ( 90\%)+ } \\
\hline \multicolumn{3}{|l|}{ Endcap/Leaded Glass ( $10 \%)$} \\
\hline Untreated & 0.055 & 0.062 \\
\hline Treated $^{a}(\mathrm{~L} / \mathrm{S} \sim 2.9)^{b}$ & 0.027 & 0.044 \\
\hline Historic Data for As-Stored Crushed Lamps ${ }^{\epsilon}$ & $0.076 \pm 0.05$ & $<0.50$ \\
\hline
\end{tabular}


The aqueous wash and rinse solutions from this test were submitted for analysis to verify that mercury was solubilized from the solid debris. Assuming an average total mercury content of $\sim 80 \mathrm{mg} / \mathrm{g}$ on the glass/phosphor solids (from the direct analysis), a 100-g sample should contain a total of $\sim 8 \mathrm{mg} \mathrm{Hg}( \pm 30 \%$ ). Replicate samples indicated total recovery of solubilized mercury in the wash and rinse solutions of $\sim 3-7.5 \mathrm{~g}$, or nominal recoveries of $\sim 38-96 \%$. This data is similar to the results reported by Gates et al. (1995 A,B) for the solubilization of elemental mercury from glass/phosphor component by a large excess of oxidant/complexing reagent.

A second series of washing was conducted in a manner similar to the first, except that (1) $400 \mathrm{~g}$ of glass/phosphor and $860 \mathrm{~g}(\sim 820 \mathrm{~mL})$ of bleach/salt wash solution were contacted (i.e., $\mathrm{L} / \mathrm{S}=2.1)$, followed by a water-rinse at $L / S=2.5$, and (2) phase separation was by simple decantation (versus filtration). Mercury in the TCLP extract of washed lamp shards ( $<0.0013 \mathrm{mg} / \mathrm{L}$ ) was well below the UTS success criterion $(<0.025 \mathrm{mg} / \mathrm{L})$. However, analysis of mercury in the filtered wash and rinse solutions suggested that the mercury actually solubilized was $<10 \%$ of the nominal total amount present. This data suggests that oxidant concentration may become a limiting reagent and should be monitored to ensure that it remains in excess during the treatment. It also suggests that it may not be necessary to solubilize the mercury, but that it may be possible to remove the phosphor and associated mercury particulate by rinsing and filtration alone (vide infra).

\section{Testing with Endcap Assembly Component}

As shown in Table 5, the TCLP extract for untreated endcap assemblies contained mercury at only 0.023 $\mathrm{mg} / \mathrm{L}$. Treatment of the endcap assemblies with the aggressive bleach/salt solution $(\mathrm{L} / \mathrm{S}=7.8)$ and subsequent water-rinse $(\mathrm{L} / \mathrm{S}=9.1)$ yielded solids that gave appoximately half this concentration of mercury in the TCLP leachate (see Table 5).

\section{Testing with Proportionate Mixtures of Glass/Phosphor and Endcap Assemblies}

Solids tested consisted of $20 \mathrm{~g}$ (6.8 wt \%) endcap assemblies plus $274 \mathrm{~g}(93.2 \mathrm{wt} \%)$ glass/phosphor. Treatment was with $\sim 860 \mathrm{~g}$ bleach/salt solution $(\mathrm{L} / \mathrm{S} \sim 2.9)$, in a sealed jar placed on a rolling mill for 6 hours. This wash solution was decanted and replaced with $1000 \mathrm{~g}$ distilled water rinse $(\mathrm{L} / \mathrm{S}=3.4)$, and the jar was again placed on a rolling mill. The washed, rinsed solids were separated by filtration through coarse and fine media. The TCLP extract for the isolated solids yielded a mercury concentration of $0.027 \mathrm{mg} / \mathrm{L}$, which is slightly above the UTS criterion of $0.025 \mathrm{mg} / \mathrm{L}$. It is likely that the UTS criterion could be consistently met with use of a higher liquid-to-solid ratio and/or a higher concentration of the oxidant reagent. 
Treatment of crushed lamp components containing endcap assemblies with a solution of beach and salt produces a dark-colored colloidal suspension in the unfiltered supernate solution, perhaps due to leached iron or other corrosion products. It is probable that iron and aluminum in the endcap assembly consume the hypochlorite in the wash solution (by corrosive reaction), rapidly depleting its availability for solubilizing mercury.

\subsection{Preliminary Investigations in Support of an Alternate Treatment Flowsheet}

\section{Preliminary Testing: Rinse Only}

It may be possible to achieve the treatment goals by removal of the phosphor phase, with its associated elemental mercury, without the requirement for mercury dissolution. This would make a greatly simplified process flowsheet (see Figure 10), and would avoid the use of corrosive oxidant/complexing agent solutions. Rinsing with dilute mild reducing agents should help to minimize the solubilization of mercury during processing.

In initial testing of this concept, $1922 \mathrm{~g}$ of glass/phosphor (90.7 wt \%) and $198 \mathrm{~g}$ of endcap assemblies (9.3 wt \%) were contacted in a sealed jar with $2750 \mathrm{~g}$ process water containing $23 \mathrm{~g}$ granular sodium bisulfite $\left(\mathrm{NaHSO}_{3}\right.$, from J.T. Baker Chemical Co.), for an L/S of 1.3. This L/S ratio simulates transferring the contents of a as-stored 55 -gallon drum ( $75 \%$ filled with crushed lamps) to an 80-gallon drum, which is filled to $94 \%$ total capacity by the addition of 58 -gallon of $\sim 0.08 \mathrm{~mol} / \mathrm{L}$ bisulfite/metabisulfite solution before sealing the drum and contacting phases by roll mixing. In the laboratory-scale testing, phases were contacted by rolling for 4 hours. The jar contents were allowed to stand overnight ( 16 hours) before separating phases by draining the contents through mylon screen. The drained solids were rinsed by the addition of $2750 \mathrm{~g}$ of process water, and again mixed by rolling for 4 hours before again draining the liquid phase. The drained bulk solids were submitted for TCLP analysis, which yielded a value of $0.012 \mathrm{mg} \mathrm{Hg} / \mathrm{L}$ in the leachate, which is well below the UTS criterion.

In a second test, $1030 \mathrm{~g}$ of glass/phosphor ( $95.5 \mathrm{wt} \%$ ) and $49 \mathrm{~g}$ of endcap assemblies (4.5 wt \%) were contacted with $2750 \mathrm{~g}$ of $\sim 0.08 \mathrm{~mol} / \mathrm{L}$ bisulfite solution, for $\mathrm{L} / \mathrm{S} \sim 2.5$. As before, the contents were mixed by rolling, the liquid drained and replaced by process water for a final rinse. The TCLP analysis for the drained solids again yielded a value of $0.012 \mathrm{mg} \mathrm{Hg} / \mathrm{L}$ in the leachate.

Some preliminary tests were performed to confirm that mercury was actually removed by the rinse-only process. In order to harvest sufficient "phosphor" phase to permit direct analysis of its mercury content, seven unused intact lamps were crushed (total mass, $1987 \mathrm{~g}$ ); the crushed solids were contacts with $2750 \mathrm{~mL}$ of $\sim 0.09$ mol/L bisulfite solution (L/S 1.4) by rolling in a sealed jar for 4 hours. Phosphor and some very fine glass shards were isolated from the larger solids by filtering the jar contents through plastic screen (equivalent to Tyler 14 mesh), and the fine solids in the filtrate slurry were harvested by centrifugation. On a dry-weight equivalent basis, 


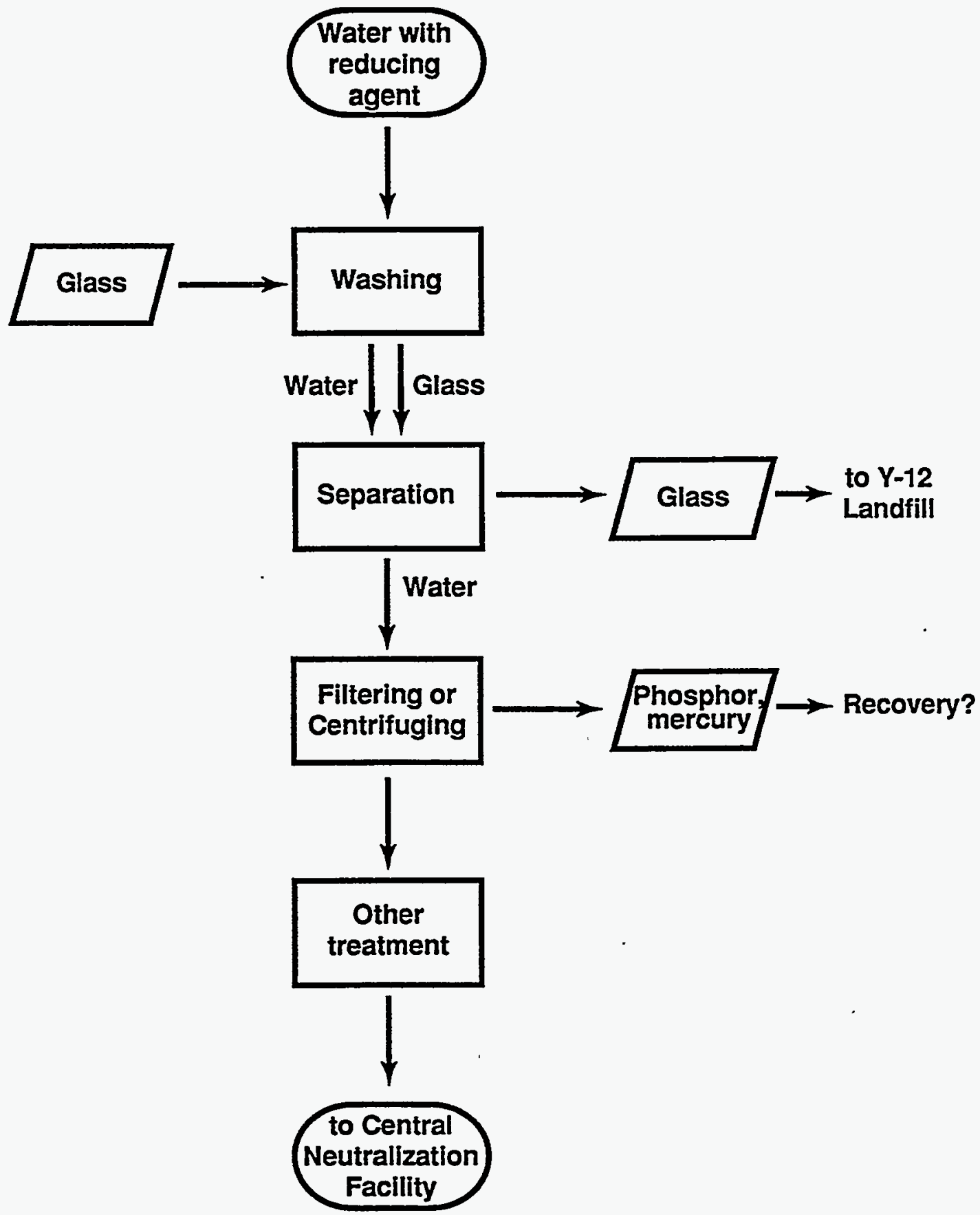

Figure 10. Proposed process flowsheet to remove mercury-containing phosphor particulate from crushed fluorescent lamps by rinsing with water containing a mild reducing agent. 
a total of $37.5 \mathrm{~g}$ of phosphor/fines (1.9\% of total lamp mass) were collected, having a mercury content of about $2,400 \mu \mathrm{g} / \mathrm{g}$. Thus, a large proportion of the mercury in the lamps tended to follow the phosphor/fines in the rinse solution. Mercury solubility in the rinse solution was minimal $(<0.05 \mathrm{mg} / \mathrm{L}$ ) [a saturated solution of $\mathrm{Hg}$ (liq) in water at $20^{\circ} \mathrm{C}$ contains $0.02-0.03 \mathrm{mg} / \mathrm{L}$ soluble mercury (Burrows et al., 1974)].

\subsection{Proposed Apparatus for Pilot-Scale Treatability Demonstration}

The flowsheet depicted in Figure 11 could be used to scale up either of the proposed redox treatment processes but is presented in terms of the bisulfite solution displacement of phosphor and other fine particulate (see previous section). The initial step is coarse screening to remove incidental large debris (e.g., respirator cartridges) that may have been placed in the drums.

Next, the solids and wash solution would be contacted; this could be accomplished with use of a tilt mixer. A small mobile cement mixer could process the contents of one drum per batch, whereas a stationary Mina-Mixer (Munson Machinery Co., Utica, NY 13503) could process 2-3 drums of crushed lamps per batch. After contacting the phases, the mixer contents could be transferred to a high-efficiency vibratory screen platform (available from, e.g., Smico Manufacturing Co., Oklahoma City, OK 73127). The unit can be configured to simultaneously produce several different size fractions. A coarse mesh screen could separate relatively large components, such as endcap assemblies, from intermediate size material (washed glass). The washed glass represents the largest mass fraction of the crushed lamps and can be tested against the Waste Acceptance Criteria for the Y-12 Sanitary Landfill. Alternately, engineers for the Transportable Vitrification System have expressed interest in the low mercury washed glass component, without endcap assemblies, for use as a waste silica source for co-immobilization of low-level waste in a glassy matrix (L. R. Dole, Lockheed Martin Energy Systems, personal communication to W. D. Bostick, Lockheed Martin Energy Systems, June 20, 1995). Wash water with fine particulate, including phosphor slurry, is collected in a sump for recycle or further processing.

Results presented in Section 4 suggest that mercury tracks with the phosphoror phase. Removal of fine phosphor from aqueous suspension can be accomplished with the use of the V-Sep filtration unit (New Logic International, Emeryville, CA 94608). This novel continuous filtration system uses a vibratory shear force at the membrane filter surface, allowing a high filtrate flux without clogging the membrane surface. To test the performance of this novel system, we provided the vendor with a sample of virgin phosphor (production-grade material, before addition of mercury, kindly provided by General Electric Corp.). This material in slurry was demonstrated to be extremely easy to filter in the vendor test. The vendor suggests that, with use of a Trisep 
Polysulfone membrane filter, the unit can yield a high-flux clear permeate (filtrate) solution and a concentrated solids stream (containing 50-60 wt \% solids) (M. Monroe and B. Culkin, New Logic International, correspondence to K. T. Bowser, Lockheed Martin Energy Systems, January 1996). The small-volume concentrated solids stream can be containerized as RCRA hazardous waste or should be amenable to resource recovery (the mercury content should be more concentrated than in the original waste by a factor of $>100$ ).

Steel wool cannisters can be used as a final "polishing step". to remove any solubilized mercury before the filtrate is transported to the CNF for iron co-precipitation and ultimate discharge. The Rotex model M-24 cannister (Rotex Silver Recovery Co., Springfield, OH 45503) contains $\sim 24 \mathrm{lbs}$ of steel wool and has a recommended solution throughput of $>14 \mathrm{gal} / \mathrm{h}$.

In order to minimize the possibility of transfer of soluble mercury to the CNF, performance of the steel wool reagent cannister should be monitored to ensure that its treatment capacity has not been exceeded. Use of a translucent reagent cannister (such as illustrated in Fig. 6) facilities visual confirmation that active reagent is still available, but use of a continuous, on-line monitor for soluble mercury would offer greater performance assurance. Colleagues at the Oak Ridge Y-12 Plant have recently evaluated an automated commercial electrochemical sensor (model 4800 on-line metals monitors, Ionics Corp., a division of Chemtronics, Ltd.) for mercury in aqueous solution. They report a reliable instrument operating range of $0.02-1.0 \mathrm{mg} / \mathrm{L}$ (Smith and Godfrey, 1995). If the concentration of mercury is determined to be above a set threshold value, a transducer signal could be generated to actuate a valve to divert the solution flow to a fresh treatment cannister; the spent camister would be removed from service, and retained for possible resource recovery. This system would provide assurance that mercury in solution collected for transfer to the CNF is within acceptable limits. 


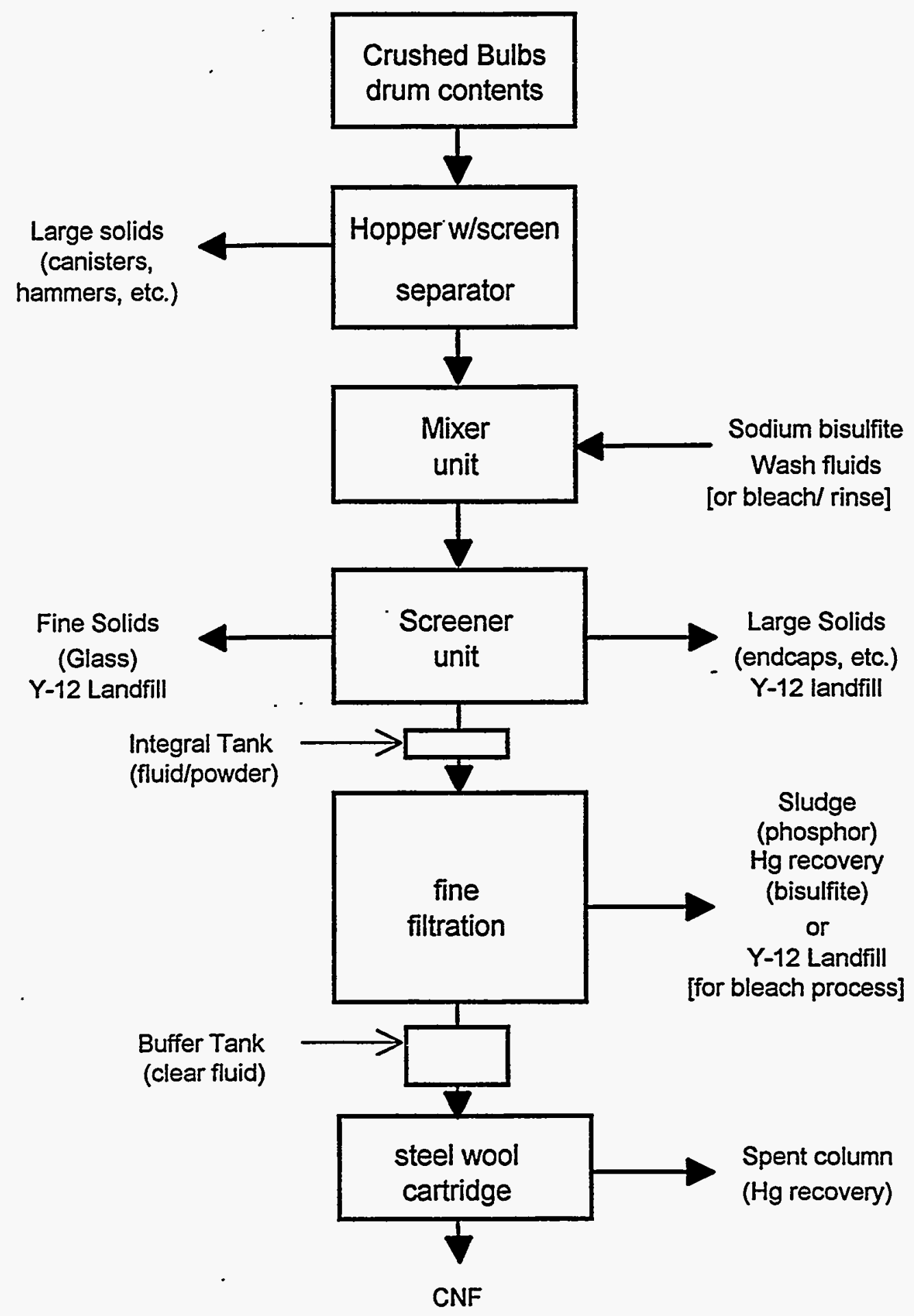

Figure 11. Flow sheet of proposed redox treatment process for removal of mercury from crushed fluorescent lamps. 
, 


\section{CONCLUSIONS}

As others have noted, hypochlorite (bleach) is an effective reagent to solubilize elemental mercury. We applied this approach to solubilization of mercury in components of crushed fluorescent lamps. The glass/phosphor component contains the great majority of the total mercury. For this component, solubilization appeared successful, providing that a large stoichiometric excess of hypochlorite was available. In the presence of endcap assembly components, solubilization of mercury by hypochlorite/chloride wash solution appeared less complete. It is possible that the residual solids may contain sorbed mercury that might cause the treated solids to not consistently meet the qualifying criterion for land disposal mercury-containing waste (viz, <0.025 $\mathrm{mg} \mathrm{Hg} / \mathrm{L}$ in the TCLP test leachate). The metal components of the endcaps (aluminum casing and iron filaments, etc.) may consume the oxidant reagent (by corrosion) and may complicate the overall redox chemistry (note in Table 3 that $\mathrm{Al}$, if stripped of its protective oxide coating, is a potent reducing/cementation agent). It may be possible to consistently treat crushed lamps to the land disposal criterion for mercury with use of a large excess of oxidant. Alternately, the large endcap assemblies could be separated from the smaller, lighter glass/phosphor shards and the components treated separately.

Mercury is shown to be effectively removed from aqueous solution by cementation with zero-valence iron in the form of steel wool. In our testing, steel wool performed well for the removal of complexed mercuric ion in saline solution under conditions of dynamic flow. Steel wool reagents are available from several manufacturers in the convenient form of prepackaged chemical recovery cartridges, which are used primarily for the recovery of silver ion from photographic waste.

It may also be possible to achieve the treatment goals by removal of the phosphor phase, with its associated elemental mercury, without the requirement for mercury dissolution. This concept was successfully tested by rinsing a mixture of lamp components with a solution of dilute mild reducing solution (to suppress dissolution of mercury), followed by a water rinse to remove residual reagent solution.

Effective implementation of this alternative will require removal of fine particulate with its associated mercury phase from the rinse slurry; this small volume of fine particulate waste, enriched in mercury content should be amendable to recovery of mercury by (e.g.) thermal retorting. If bisulfite solution is used in the rinse process, excess reagent, after mercury recovery, may be converted to innocuous sulfate ion by air oxidation. 



\section{ACKNOWLEDGMENTS}

The authors wish to thank Dr. Donald Foust, General Electric Corporation, for sharing information regarding mercury distribution in fluorescent lamp components. We thank M. J. Shelton of the K-25 Site Waste Management Organization for sponsoring these investigations. 



\section{REFERENCES}

Bostick, W. D. ,D. P. Hoffmann, D. H. Bunch, and L. V. Gibson, Jr., 1992. "Effluent Testing at the Oak Ridge Mixed Waste Incinerator," Paper 92-38.02, Proceedings, 85th Annual Meeting \& Exposition of the Air \& Waste Management Association, Kansas City, Missouri, June 21-26.

Bostick, W. D., D. P. Hoffmann, R. J. Stevenson, A. A. Richmond, and D. F. Bickford, 1994. Surrogate Formulations for Thermal Treatment of Low-Level Mixed Waste: Part IV-Wastewater Treatment Sludges, Report DOE/MWIP-18, Martin Marietta Energy Systems, Inc., Oak Ridge, Tennessee.

Bostick, W. D., P. E. Osborne, G. D. Del Cul, and D. W. Simmons, 1995. Treatment of Aqueous Solutions Contaminated with Technetium-99 Originating from Uranium Enrichment Activities: Final Report, Report K/TCD-1120, Martin Marietta Energy Systems, Inc., Oak Ridge, Tennessee.

Bostick, W. D., P. E. Osborne, D. E. Beck, D. H. Bunch, R. L. Fellows, G. F. Sellers, J. L. Shoemaker, and K. T. Bowser 1995. Removal of Technetium-99 from Simulated Oak Ridge National Laboratory NewlyGenerated Liquid Low-Level Waste, Report K/TCD-1141, Martin Marietta Energy Systems, Inc., Oak Ridge, Tennessee.

Burrows, W. D., R. S. Reimers, and E. B. Shin, 1974. "Chemistry of Mercury in the Environment," CRC Critical Rev. Environmental Control,4, 251.

Cantrell, K J., D. I. Kaplan, and T. W. Wietsma 1995. "Zero-Valent Iron for the In-Situ Remediation of Selected Metals in Groundwater," J. Haz Mat. 42, 201.

Cooney, E., B. Luo, J. W. Patterson, and C. Petropoulou, 1992. "Toxicity Reduction Methodologies," Chapter 5 in Toxicity Reduction, Evaluation and Control, D. L. Ford, Ed., Techomic Publishers, Inc., Lancaster, Pennsylvania.

Del Cul, G. D., and W. D. Bostick 1995. "Simple Method for Technetium Removal from Aqueous Solutions," in Nuclear Technology. 101 (1), 161.

Foust, D. F. 1993. "Extraction of Mercury and Mercury Compounds from Contaminated Material and Solutions," U.S. Patent 5,226,545.

Gates, D. D., K. K. Chao, and P. A. Cameron 1995. The Removal of Mercury from Solid Mixed Waste Using Chemical Leaching Processes, Report ORNL/TM-12887, Oak Ridge National Laboratory, Oak Ridge, Tennessee.

Gates, D. D., et al. 1995."Mercury Removal from Liquid and Solid Mixed Waste," presented at "Procedure Waste Management '95," Tucson, Arizona, February 26-March 2.

Hess, P. 1992. "Silver Recovery: EPA Compliance for Corporate Photo Labs," Photo-Electronic Imaging, p. 21.

Grau, J. M., and J. M. Bisang 1995. "Removal and Recovery of Mercury from Chloride Solutions by Contact Deposition on Iron Felt," J. Chem. Tech. Biotechnol. 62, 153. 
Luckey, T. D., B. Venugopal, and D. Hutcheson 1975. Heavy Metal Toxicity, Safety and Hormonology, Academic Press, New York.

Meyer, V. D. 1992. "Inter-Laboratory Testing for Mercury by TCLP and Source Reduction in the Lamp Manufacturing Industry," in Arsenic and Mercury: Workshop on Removal, Recovery, Treatment, and Disposal, Report EPA/600/R-92/105, U.S. Environmental Protection Agency, August, p. 86.

Pedroso, A. C. S., L. E. R. Gomes, J. M. R. de Carvaiho 1994. "Mercury Removal from Process Sludges via Hypochlorite Leaching," Environmental Technology 15, 657.

Pourbaix, M., 1974. Atlas of Electrochemical Equilibria in Aqueous Solutions, 2nd English ed., National Association of Corrosion Engineers, Houston, Texas.

Rockandel, M. 1992. "Non-Thermal Processing of K106 Mercury Mud" in Arsenic and Mercury: Workshop on Removal, Recovery, Treatment, and Disposal, Report EPA/600/R-92/105, U.S. Environmental Protection Agency, August, p. 117.

Smith, D. D., and Godfrey, B. W., 1995, Application/Demonstration of an On-Line Mercury-in-Water Monitor, Report Y/DZ-1141, Martin Marietta Energy Systems, Inc., Oak Ridge, Tennessee.

Stockdale, J. A. D., H. T. Lee, W. D. Bostick, and D. P. Hoffmann, 1994. Surrogate Formulations for Thermal Treatment of Low-Level Mixed Waste: Part I-Radiological Surrogate, Report DOE/MWIP-15, Martin Marietta Energy Systems, Inc., Oak Ridge, Tennessee.

Truesdale, R. S., S. M. Beaulieu, and T.K. Pierson 1993. Management of Used Fluorescent Lamps: Preliminary Risk Assessment, prepared by Research Triangle Institute, Research Triangle Park, North Carolina, for Office of Solid Waste, U.S. Environmental Protection Agency.

Tyson, D. R. 1993. “Treatability Study for the Amalgamation of a Radioctively Contaminated Elemental Mercury Waste at the Idaho National Engineering Laboratory," in Proceedings of Second International Symposium on Mixed Waste, A. A. Moghissi et al., Eds., Baltimore, Maryland, August 17-20, p. 14.2.1.

U.S. Environmental Protection Agency, 1994. Evaluation of Mercury Emissions from Fluorescent Lamp Crushing, Report EPA-453/D-94-018, U. S. Environmental Protection Agency. 
APPENDIX A

SAMPLE DATA 


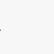


SAMPLE IDs

\begin{tabular}{|c|c|c|c|}
\hline & ANALIS ID & Customer ID & Description \\
\hline & \multicolumn{3}{|c|}{$\begin{array}{l}\text { The following two samples were analyzed for mercury instead of for mercury on the } \\
\text { TCLP extraction solution: }\end{array}$} \\
\hline & $950606-001$ & $D$ & Untreated glass from jar D \\
\hline & $950606-002$ & $F$ & Untreated glass from jar $F$ \\
\hline \multirow{4}{*}{ Test I } & \multicolumn{3}{|c|}{$\begin{array}{l}\text { (1) } 100 \text { grams of glass and a solution of } 720 \mathrm{ml} \text { distilled water, } 60 \text { grams of salt, and } \\
80 \mathrm{ml} \text { of lab-grade bleach were placed in a gallon glass jar and rolled on Gary's roller } \\
\text { mill for } 6 \text { hours. This was then filtered through first a coarse filter (Whatman 54) and } \\
\text { then through a fine filter ( } 1: \text { membrane filter). } \\
\text { (2) Next the glass was returned to the gallon jar along with } 1000 \mathrm{ml} \text { of distilled water. } \\
\text { This was rolled for } 2-4 \text { hours. Then the wash water was filtered through the coarse and } \\
\text { fine filters. }\end{array}$} \\
\hline & $950616-042$ & $060995-1$ & Leach solution for jar D \\
\hline & $950616-044$ & $061295-1$ & Rinse water for jar D \\
\hline & $950616-046$ & $061295-3$ & Treated glass from jar D \\
\hline \multirow{10}{*}{ Test II } & \multicolumn{3}{|c|}{$\begin{array}{l}\text { (1) } 100 \text { grams of glass and a solution of } 720 \mathrm{ml} \text { distilled water, } 60 \text { grams of salt, and } \\
80 \mathrm{ml} \text { of lab-grade bleach were placed in a gallon glass jar and rolled on Gary's roller } \\
\text { mill for } 6 \text { hours. This was then filtered through first a coarse filter (Whatman 54) and } \\
\text { then through a fine filter ( } 1 \text { : membrane filter). } \\
\text { (2) Next the glass was returned to the gallon jar along with } 1000 \mathrm{ml} \text { of distilled water. } \\
\text { This was rolled for } 2-4 \text { hours. Then the wash water was filtered through the coarse and } \\
\text { fine filters. }\end{array}$} \\
\hline & $950616-043$ & $060995-2$ & Leach solution for jar $F$ \\
\hline & $950616-045$ & $061295-2$ & Rinse water for jar $F$ \\
\hline & $950616-047$ & $061295-4$ & Treated glass from jar $F$ \\
\hline & \multicolumn{3}{|c|}{$\begin{array}{l}\text { The following samples were submitted to get TCLP analysis on the glass from jars } B \text {, } \\
\text { D, F, and J. }\end{array}$} \\
\hline & 950719-284 & $12118-127-\mathrm{F}$ & Untreated glass from jar $F$ \\
\hline & $950719-285$ & $12118-127-\mathrm{D}$ & Untreated glass from jar D \\
\hline & $950802-039$ & D & Untreated glass from jar D \\
\hline & $950802-038$ & 121118-127-J & Untreated glass from jar J \\
\hline & $950802-040$ & 12118-127-B & Untreated glass from jar B \\
\hline \multirow{4}{*}{ Test III } & \multicolumn{3}{|c|}{$\begin{array}{l}\text { (1) } 400 \text { grams of glass and a solution of } 720 \mathrm{ml} \text { distilled water, } 60 \text { grams of salt, and } \\
80 \mathrm{ml} \text { of lab-grade bleach were placed in a gallon glass jar and rolled on Gary's roller } \\
\text { mill. The liquid was decanted off the glass. This was then filtered through first a coarse } \\
\text { filter (Whatman 54) and then through a fine filter ( } 1 \text { : membrane filter). } \\
\text { (2) Next the glass was retumed to the gallon jar along with } 1000 \mathrm{ml} \text { of distilled water. } \\
\text { This was roiled. Then the wash water was filtered through the coarse and fine filters. }\end{array}$} \\
\hline & 950719-286 & 070595-1 & Leach solution for jar D \\
\hline & $950719-289$ & 070795-1 & Rinse water for jar D \\
\hline & $950802-041$ & 12118-127-D1 & Treated glass from jar $D$ \\
\hline
\end{tabular}




\begin{tabular}{|c|c|c|c|}
\hline & ANALIS ID & Customer ID & Description \\
\hline \multirow{4}{*}{ Test } & \multicolumn{3}{|c|}{$\begin{array}{l}\text { (1) } 400 \text { grams of glass and a solution of } 720 \mathrm{ml} \text { distilled water, } 60 \text { grams of salt, and } \\
80 \mathrm{ml} \text { of lab-grade bleach were placed in a gallon glass jar and rolled on Gary's roller } \\
\text { mill. The liquid was decanted off the glass. This was then filtered through first a coarse } \\
\text { filter (Whatman 54) and then through a fine filter (1: membrane filter). } \\
\text { (2) Next the glass was returned to the gallon jar along with } 1000 \mathrm{ml} \text { of distilled water. } \\
\text { This was rolled. Then the wash water was filtered through the coarse and fine filters. }\end{array}$} \\
\hline & $950719-287$ & $071295-1$ & Rinse water for jar $F$ \\
\hline & $950719-288$ & $070695-1$ & Leach solution for jar $F$ \\
\hline & $950802-042$ & $12118-127-\mathrm{F} 1$ & Treated glass from jar $F$ \\
\hline \multirow{5}{*}{ Test V } & \multicolumn{3}{|c|}{$\begin{array}{l}\text { (1) } 110 \text { grams of endcaps were used. The leach solution was } 60 \mathrm{~g} \text { salt, } 80 \mathrm{ml} \text { of lab- } \\
\text { grade bleach, and } 720 \mathrm{ml} \text { of distilled water. After rolling on the rolling mill, the liquid } \\
\text { was decanted off the glass. This was then filtered through first a coarse filter (Whatman } \\
\text { 54) and then through a fine filter ( } 1 \text { : membrane filter). } \\
\text { (2) Next, the solids were returned to the gallon jar along with } 1000 \mathrm{ml} \text { of distilled } \\
\text { water. This was rolled. Then the wash water was filtered through the coarse and fine } \\
\text { filters }\end{array}$} \\
\hline & $\begin{array}{l}950824-056 \\
\text { and } 057^{\circ}\end{array}$ & $12118-131-1$ & Treated endcaps \\
\hline & $\begin{array}{l}950824-060 \\
\text { and } 061^{*}\end{array}$ & $12118-129-1$ & Leach solution for endcaps \\
\hline & $\begin{array}{l}950824-066 \\
\text { and } 067^{*}\end{array}$ & $12118-131-2$ & Rinse water for endcaps \\
\hline & $950921-088$ & $12118-132-1$ & Untreated endcaps \\
\hline \multirow{5}{*}{ Test VI } & \multicolumn{3}{|c|}{$\begin{array}{l}\text { The samples below were generated during leach tests on a mixture of endcaps and glass. } \\
\text { (1) } 20 \text { grams of endcaps plus } 274 \text { grams of glass were used. The leach solution was } 60 \\
\text { g salt, } 80 \mathrm{ml} \text { of lab-grade bleach, and } 720 \mathrm{ml} \text { of distilled water. After rolling on the } \\
\text { rolling mill, the liquid was decanted off the glass. This was then filtered through first a } \\
\text { coarse filter (Whatman } 54 \text { ) and then through a fine filter ( } 1 \text { : membrane filter). } \\
\text { (2) Next the solids were returned to the gallon jar along with } 1000 \mathrm{ml} \text { of distilled water. } \\
\text { This was rolled. Then the wash water was filtered through the coarse and fine filters }\end{array}$} \\
\hline & $\begin{array}{l}950824-054 \\
\text { and } 055^{*}\end{array}$ & $12118-131-3$ & Treated mixture of endcaps and glass \\
\hline & $\begin{array}{l}950824-062 \\
\text { and } 063^{*}\end{array}$ & $12118-131-4$ & Rinse water for mixture of endcaps and glass \\
\hline & $\begin{array}{l}950824-064 \\
\text { and } 065^{*}\end{array}$ & $12118-130-1$ & Leach solution for mixture \\
\hline & $950921-089$ & $12118-132-2$ & Untreated mixture of glass and endcaps \\
\hline & \multicolumn{3}{|c|}{$\begin{array}{l}\text { The following samples were generated during a test to evaluate the use of rinsing to } \\
\text { separate the glass and the phosphor. This test was scaled to model the treatment of the }\end{array}$} \\
\hline
\end{tabular}

\footnotetext{
"We submitted one sample to ASO. They divided it into two samples

"We submitted one sample to ASO. They divided it into two samples.

-We submitted one sample to ASO. They ran the TCLP and divided the resulting extraction solution into two samples.
} 
ANALIS ID Customer ID

\begin{tabular}{|c|c|c|c|}
\hline \multirow{6}{*}{$\begin{array}{l}\text { Test } \\
\text { VII }\end{array}$} & \multicolumn{3}{|c|}{$\begin{array}{l}\text { crushed bulbs and endcaps from a } 3 / 4 \text { full } 55 \text { gallon drum in a } 80 \text { gallon overpack. } \\
\text { (1) Added } 1922 \mathrm{~g} \text { of crushed glass ( } 628.4 \mathrm{~g} \text { from jar } \mathrm{D} \text { and } 1294 \mathrm{~g} \text { from jar } \mathrm{B} \text { ) and } 198 \\
\mathrm{~g} \text { of endcaps to a gallon jar. Wash solution was } 2750 \mathrm{ml} \text { of process water and } 23 \mathrm{~g} \text { of } \\
\text { sodium bisulfite ( } 0.1 \mathrm{~N} \text { sodium bisulfite solution). This was rolled on Gary's roller } \\
\text { mill. Then, the glass and endcaps were separated from the solution and phosphor by } \\
\text { pouring through plastic screening. The solution was then filtered through coarse and } \\
\text { fine filters. The glass and endcaps were returned to the jar. } \\
\text { (2) } 2750 \mathrm{ml} \text { of process water was added. The jar was rolled again. }\end{array}$} \\
\hline & 950928-048 & $12118-142-2$ & First rinse \\
\hline & NA & $12118-144-3$ & Coarse filter from first rinse \\
\hline & NA & $12118-145-1$ & Membrane filter from first rinse \\
\hline & $950928-049$ & $12118-145-2$ & Second rinse \\
\hline & $950928-051$ & $12118-145-3$ & Treated solids \\
\hline \multirow{6}{*}{$\begin{array}{l}\text { Test } \\
\text { VIII }\end{array}$} & \multicolumn{3}{|c|}{$\begin{array}{l}\text { The following samples were generated during a test to evaluate the use of rinsing to } \\
\text { separate the glass and the phosphor. This test used the same amount of the same } \\
\text { solution as the test described above, but only } 1 / 4 \text { as much glass and endcaps as the test } \\
\text { above. } \\
\text { (1) Added } 1030 \mathrm{~g} \text { of crushed glass ( } 94.8 \mathrm{~g} \text { from jar B and } 936 \mathrm{~g} \text { from jar J) and } 49.4 \mathrm{~g} \\
\text { of endcaps to a gallon jar. Wash solution was } 2750 \mathrm{ml} \text { of process water and } 23 \mathrm{~g} \text { of } \\
\text { sodium bisulfite ( } 0.1 \mathrm{~N} \text { sodium bisulfite solution). This was rolled on Gary's roller } \\
\text { mill. Then, the glass and endcaps were separated from the solution and phosphor by } \\
\text { pouring through plastic screening. The solution was then filtered through coarse and } \\
\text { fine filters. The glass and endcaps were returned to the jar. } \\
\text { (2) } 2750 \text { ml of process water was added. The jar was rolled again. }\end{array}$} \\
\hline & $950922-087$ & $12118-142-1$ & First rinse \\
\hline & NA & 12118-144-1 & Coarse filter from first rinse \\
\hline & NA & $12118-144-2$ & Membrane filter from first rinse \\
\hline & $950928-050$ & $12118-145-5$ & Second rinse \\
\hline & $950928-052$ & $12118-145-4$ & Treated solids \\
\hline \multirow{6}{*}{ Test IX } & $\begin{array}{l}\text { The } \\
\text { solu } \\
\text { (1) } \mathrm{x} \\
\text { and } \\
\text { (2) }\end{array}$ & $\begin{array}{l}\text { llowing sample } \\
\text { on. } \\
\text { ed } 180 \text { g sait, } 2 \\
0 \text { g glass. } \\
\text { (4) Rinsed thre }\end{array}$ & $\begin{array}{l}\text { re generated during a test to evaluate leaching with bleach } \\
\text { ml process water, } 240 \mathrm{ml} \text { lab-grade bleach, } 49 \text { grams endcaps, } \\
\text { nes, each time with } 2700 \mathrm{ml} \text { process water. }\end{array}$ \\
\hline & $951011-060$ & $12252-8-1$ & Leach solution \\
\hline & $951011-061$ & $12252-14-1$ & First rinse \\
\hline & $951101-075$ & $12252-14-2$ & Treated solids \\
\hline & $951101-077$ & $12252-16-1$ & Second rinse \\
\hline & $951101-076$ & $12252-17-1$ & Third rinse \\
\hline
\end{tabular}




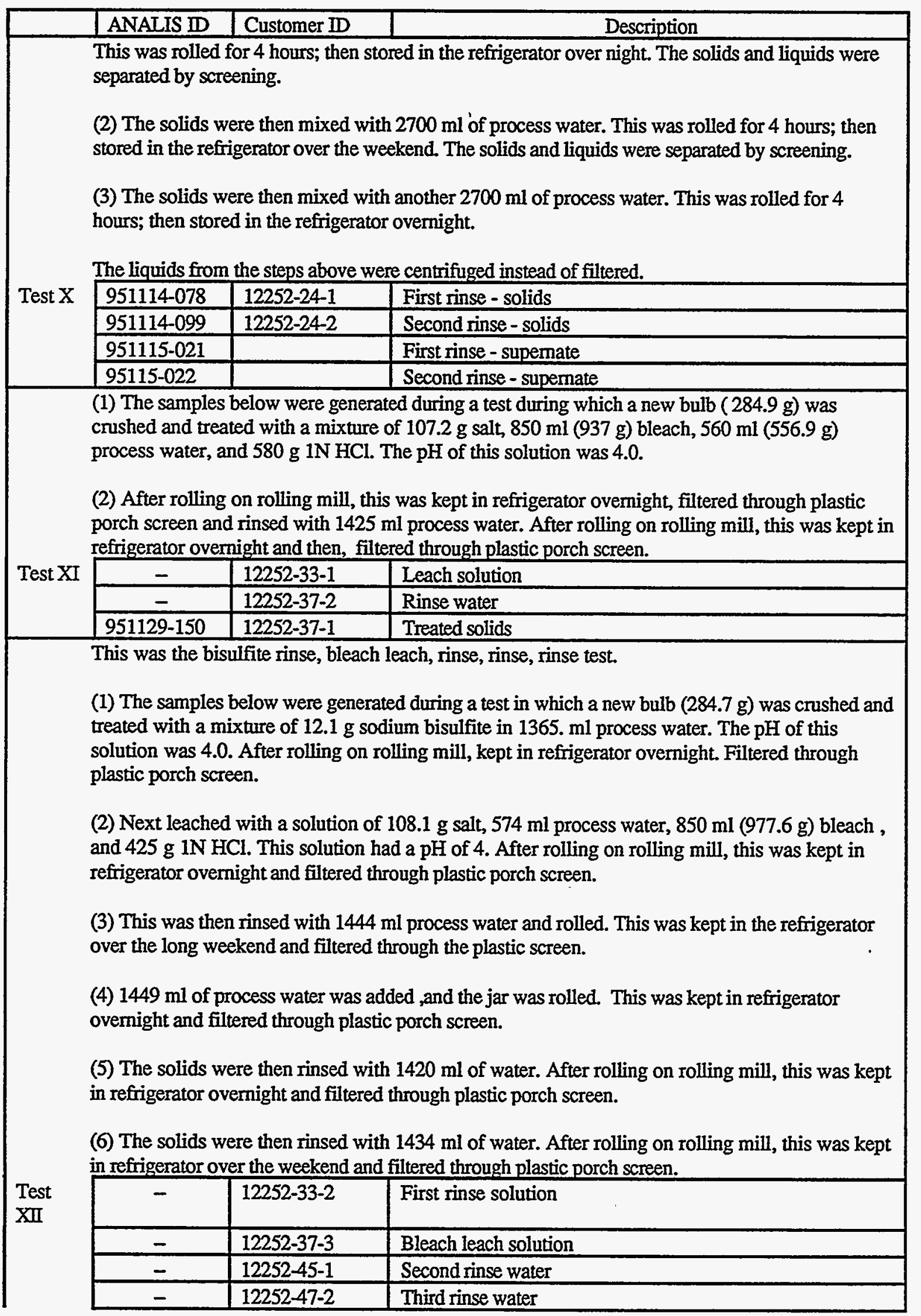


SAMPLE IDS

\begin{tabular}{|c|c|l|l|}
\hline & ANALIS ID & Customer ID & \multicolumn{1}{c|}{ Description } \\
\hline \multirow{4}{*}{} & - & $12252-53-2$ & Fourth rinse water \\
\cline { 2 - 5 } & - & $12252-55-2$ & Fifth rinse water \\
\cline { 2 - 5 } & $951206-135$ & $12252-55-1$ & Treated solids \\
\hline
\end{tabular}

This was the bleach leach, rinse, rinse, rinse test.

(1) The samples below were generated during a test in which a new bulb ( $281.5 \mathrm{~g})$ was crushed and treated with a mixture of $107 \mathrm{~g}$ salt, $570 \mathrm{ml}$ process water, $870 \mathrm{ml}(913.2 \mathrm{~g})$ bleach, and $\mathrm{HCl}$. The $\mathrm{pH}$ of this solution was 4.0.

(2) After rolling on rolling mill, this was kept in refrigerator overnight, filtered through plastic porch screen and rinsed with $1467 \mathrm{ml}$ process water.

(3) After rolling on rolling mill, this was kept in refrigerator ovemight, filtered through plastic porch screen, and rinsed with $1523 \mathrm{ml}$ of process water.

(4) This was kept in the refrigerator over the long weekend, filtered through the plastic screen and rinsed with $1495 \mathrm{ml}$ process water.

Test

XIII

\begin{tabular}{|c|l|l|}
\hline- & $12252-34-1$ & Leach solution \\
\hline- & $12252-38-1$ & First rinse \\
\hline- & $12252-45-2$ & Second rinse \\
\hline- & $12252-48-1$ & Third rinse \\
\hline- & $12252-54-2$ & Fourth rinse \\
\hline $951206-136$ & $12252-54-1$ & Treated solids \\
\hline
\end{tabular}

This was the low bleach leach, rinse, rinse, rinse test.

(1) The samples below were generated during a test in which a new bulb (281.4 g) was treated with $107.3 \mathrm{~g}$ salt, $1286 \mathrm{ml}$ process water, $140 \mathrm{ml}(158.72 \mathrm{~g})$ of bleach, and $104 \mathrm{~g} 1 \mathrm{~N} \mathrm{HCl}$. The $\mathrm{pH}$ of this solution was 3.8.

(2) After rolling on rolling mill, this was kept in refrigerator overnight, filtered through plastic porch screen and rinsed with $1427 \mathrm{ml}$ process water.

(3) After rolling on rolling mill, this was kept in refrigerator overnight, filtered through plastic porch screen, and rinsed with $1429 \mathrm{ml}$ of process water. This was rolled, then stored in the refrigerator over the long weekend.

(4) This was filtered through the plastic screen and washed with $1477 \mathrm{ml}$ process water.

(5) This was kept in the refrigerator overnight, filtered with the plastic screen, and rinsed with $1417 \mathrm{ml}$ process water.

\begin{tabular}{|c|c|c|c|}
\hline \multirow{5}{*}{$\begin{array}{l}\text { Test } \\
\text { XIV }\end{array}$} & - & $12252-35-1$ & Leach solution \\
\hline & - & $12252-38-2$ & First rinse \\
\hline & - & $12252-46-1$ & Second rinse \\
\hline & - & $12252-48-2$ & Third rinse \\
\hline & - & $12252-54-4$ & Fourth rinse \\
\hline & $951206-138$ & $12252-54-3$ & Treated solids \\
\hline
\end{tabular}

(1) The samples below were generated during a test in which a new bulb $(286.2 \mathrm{~g})$ was treated with $12.1 \mathrm{~g}$ sodium bisulfite and $1457 \mathrm{ml}$ process water.

(2) After rolling on rolling mill, this was kept in refrigerator ovemight, filtered through plastic 


\begin{tabular}{|c|c|c|c|}
\hline & ANALIS ID & Customer ID & Description \\
\hline \multirow{7}{*}{$\begin{array}{l}\text { Test } \\
\text { XV }\end{array}$} & \multicolumn{3}{|c|}{$\begin{array}{l}\text { porch screen and rinsed with } 1426 \mathrm{ml} \text { process water and } 1.8 \mathrm{~g} \text { sodium bisulfite. } \\
\text { (3) After rolling on rolling mill, this was kept in refrigerator overnight, filtered through plastic } \\
\text { porch screen, and rinsed with } 2 \mathrm{~g} \text { sodium bisulfite in } 1412 \mathrm{~g} \text { process water. After rolling on rolling } \\
\text { mill, this was kept in refrigerator overnight, and filtered through plastic porch screen. } \\
\text { (4) This was then washed with } 2 \mathrm{~g} \text { sodium bisulfite in } 1370 \mathrm{ml} \text { of process water. After rolling on } \\
\text { rolling mill, this was kept in refrigerator over the long weekend, and filtered through plastic porch } \\
\text { screen. } \\
\text { (5) THis was then washed with } 2 \mathrm{~g} \text { sodium bisulfite in } 1451 \mathrm{ml} \text { process water. After rolling on } \\
\text { rolling mill, this was kept in refrigerator overnight, and filtered through plastic porch screen. } \\
\text { (6) This was then washed with } 2.3 \mathrm{~g} \text { sodium bisulfite in } 1368 \mathrm{ml} \text { process water. After rolling on } \\
\text { rolling mill, this was kept in refrigerator overnight, and filtered through plastic porch screen. }\end{array}$} \\
\hline & - & $12252-35-2$ & First rinse \\
\hline & - & $12252-39-1$ & Second rinse \\
\hline & - & $12252-46-2$ & Third rinse \\
\hline & - & $12252-49-1$ & Fourth rinse \\
\hline & - & $12252-54-6$ & Fifth rinse \\
\hline & $951206-137$ & $12252-54-5$ & Treated solids \\
\hline \multirow{7}{*}{$\begin{array}{l}\text { Test } \\
\text { XVI }\end{array}$} & \multicolumn{3}{|c|}{$\begin{array}{l}\text { (1) The samples below were generated during a test in which a new bulb (284.2 g) was treated with } \\
107.2 \mathrm{~g} \text { salt, } 575 \mathrm{ml} \text { process water, } 870 \mathrm{ml}(973 \mathrm{~g}) \text { bleach, and } 517 \mathrm{~g} 1 \mathrm{~N} \mathrm{HCl} \text {. The } \mathrm{pH} \text { of this } \\
\text { solution was } 4.0 \text {. } \\
\text { (2) After rolling on rolling mill, this was kept in refrigerator overnight, filtered through plastic } \\
\text { porch screen and rinsed with } 1427 \mathrm{ml} \text { process water. After rolling on rolling mill, this was kept in } \\
\text { refrigerator over the long weekend, and filtered through plastic porch screen. } \\
\text { (3) The solids were then treated with } 107 \mathrm{~g} \text { salt, } 583 \mathrm{ml} \text { process water, } 850 \mathrm{ml} \text { ( } 937 \mathrm{~g} \text { bleach), and } \\
418 \mathrm{~g} \text { HCl. The pH of the solution was } 4 \text {. After rolling on rolling mill, this was kept in } \\
\text { refrigerator overnight, and filtered through plastic porch screen. } \\
\text { (4) The solids were then treated with } 108.6 \mathrm{~g} \text { salt, } 540 \mathrm{ml} \text { process water, } 850 \mathrm{ml}(929.5 \mathrm{~g}) \text { bleach, } \\
\text { and } 532.7 \mathrm{~g} 1 \mathrm{~N} \text { HCl. The pH of this solution was } 4 \text {. After rolling on rolling mill, this was kept } \\
\text { in refrigerator overnight, and filtered through plastic porch screen. } \\
\text { (5) The solids were washed with } 1354 \mathrm{ml} \text { process water. After rolling on rolling mill, this was } \\
\text { kept in refrigerator over the weekend, and filtered through plastic porch screen. } \\
\text { (9) The solids were washed with } 1349 \mathrm{ml} \text { process water. After rolling on rolling mill, this was } \\
\text { kept in refrigerator overnight, and filtered through plastic porch screen. }\end{array}$} \\
\hline & - & $12252-36-1$ & First leach \\
\hline & $=$ & $12252-44-1$ & Firs \\
\hline & $=$ & $12252-47-1$ & \\
\hline & - & & \\
\hline & $=$ & $12252-55-1$ & Second rinse \\
\hline & - & $12252-56-2$ & \\
\hline
\end{tabular}


SAMPLE IDS

\begin{tabular}{|l|l|l|ll|}
\hline & ANALIS ID & Customer ID & & Description \\
\hline & $951208-067$ & $12252-56-1$ & Treated solids & \\
\hline
\end{tabular}

Samples marked by "NA" in the "ANALIS ID" column are for Material Sciences.

A-7 
NOTEBOOK PAGES

\begin{tabular}{|c|c|c|}
\hline Test & Notebook & Pages \\
\hline $\bar{I}$ & 12118 & $121-122$ \\
\hline II & 12118 & $121-122$ \\
\hline III & 12118 & $124-127$ \\
\hline IV & 12118 & $124-127$ \\
\hline $\mathrm{V}$ & 12118 & $128,131-132$ \\
\hline VI & 12118 & $129-132$ \\
\hline VII & 12118 & $136,139-142,144-145$ \\
\hline VIII & 12118 & $137-142,144-145$ \\
\hline IX & 12118 & 147 \\
\hline $\mathrm{X}$ & $\begin{array}{l}12133 \\
12252 \\
\end{array}$ & $\begin{array}{l}29 \\
22-24,27 \\
\end{array}$ \\
\hline $\mathrm{XI}$ & $\begin{array}{l}12133 \\
12252 \\
\end{array}$ & $\begin{array}{l}30 \\
28,33,37\end{array}$ \\
\hline XII & $\begin{array}{l}12133 \\
12252\end{array}$ & $\begin{array}{l}30 \\
29-30,33-34,37,45,47,53,55, \\
68\end{array}$ \\
\hline XIII & $\begin{array}{l}12133 \\
12252 \\
\end{array}$ & $\begin{array}{l}30 \\
30,34,38,45,48,53,54\end{array}$ \\
\hline XIV & $\begin{array}{l}12133 \\
12252 \\
\end{array}$ & $\begin{array}{l}30 \\
31,34-35,38,46,48,54\end{array}$ \\
\hline $\mathrm{XV}$ & $\begin{array}{l}12133 \\
12252 \\
\end{array}$ & $\begin{array}{l}30 \\
31,35,39,46,49,54\end{array}$ \\
\hline $\mathrm{XVI}$ & $\begin{array}{l}12133 \\
12252\end{array}$ & $\begin{array}{l}30 \\
32,35-36,44,47,53,55,56\end{array}$ \\
\hline
\end{tabular}


APPENDIX B

REVIEW OF ANALYTICAL DATA

FOR CRUSHED FLUORESCENT LAMPS 
Date: 25 August 1995

To: Beck, Bowser, Bunch, Fellows, Neff, Sellers

CC: Broussard, Gibson, Lyles, Astoria

From: Bostick

Subject: Review of Analytical Data for Crushed Fluorescent Lamps

This note is an update to my earlier memo of 27 July 1995.

1. "Policy Statement"

'RCRA Status of Spent Fluorescent and Other Lamps,' MMES Environmental Advisory (July 1992).

"(MMES's) environmental staff has tested various fluorescent lamps using the (TCLP) and has found that the majority of those lamps tested hazardous for the mercury characteristic...This finding has essentially been corroborated by an industry group and by the EPA. However, interlaboratory analytical variability (same lamps, different labs) can be great......the variability between labs was nearly three orders of magnitude."

\section{TCLP Testing by Lamp Manufactures}

This information is based upon the article 'Inter-Laboratory Testing for Mercury by TCLP and Surce Reduction in the Lamp Manufacturing Industry," by V. D. Meyer (from EPA/600/R92/105, August 1992; copy courtesy of D. Foust, G.E.).

In Phase III of the inter-laboratory study, one contract lab crushed a batch of standard 4-ft lamps (consecutively manufactured units from a single manufacturer), and each participating analytical lab received a subsample of this material for analysis. In Phase IV testing, the participating labs received intact lamps to crush and to perform TCLP testing. Results are summarized in Table 1. There was a great deal of inter-laboratory variation in the reported results, but consensus indicates that the lamps fail the toxicity criterion for mercury $(0.20 \mathrm{mg} / \mathrm{L}$ in the TCLP leachate). 
Table 1. Inter-Laboratory Variation in TCLP Results for Mercury in Fluorescent Lamps

Laboratory Mean TCLP results for $\mathrm{Hg}(\mathrm{mg} / \mathrm{L})$ :

Crushed Lamps Whole Lamps

$\begin{array}{lll}1 & 0.010 \pm 0.007 & 0.012 \pm 0.01 \\ 2 & 0.40 \pm 0.08 & 0.58 \pm 0.07 \\ 3 & 0.49 \pm 0.06 & 0.44 \pm 0.08 \\ 4 & 0.51 \pm 0.06 & 0.47 \pm 0.14 \\ 5 & 0.94 \pm 0.35 & 1.87 \pm 0.81 \\ 6 & 0.105 \pm 0.03 & 0.02 \pm 0.006 \\ 7 & 3.09 \pm 2.11 & 0.08 \pm 0.02 \\ 8 & & 0.58 \pm 0.23\end{array}$

Mean $\quad 0.78 \pm 1.21 \quad 0.505 \pm 0.63$

3. TCLP Testing at ORNL

Source: M. P. Maskarinec, "Leaching of Mercury from Fluorescent Light Bulbs," ORNL/CF91/361 (November 12, 1991). ['Internal Use Only']

Previous testing by the EP-Tox protocol had not indicated that Fluorescent lamps were characteristically hazardous (e.g., Hg in the extract solution was consistently less than the toxicity defining criterion of $0.20 \mathrm{mg} / \mathrm{L}$ ). This study was intended to compare Toxicity Characteristic testing performance for Fluorecent Lamps, as performed by the earlier (EP-Tox) and more recent (TCLP) protocols. Used bulbs delvered to lab intact, before size-reduction for TCLP. Results summarized in Table 2 (10 different bulb types, one blank): 
Table 2: Analysis for Mercury in TCLP extract of Crushed Fluorescent Lamps

IAL ID $\quad \mathrm{Hg}(\mathrm{mg} / \mathrm{L})$ in TCLP Extract

(duplicate samples)

$\begin{array}{ll}911101-067,-068 & \mathbf{0 . 7 5 , 0 . 7 1} \\ 911101-069,-070 & \mathbf{0 . 3 1 , 0 . 2 6} \\ 911101-071,-072 & \mathbf{0 . 2 6 , 0 . 1 9} \\ 911101-073,-074 & \mathbf{0 . 8 6 , 0 . 9 1} \\ 911101-075,-076 & 0.15,0.12 \\ 911101-077,-078 & 0.18,0.18 \\ 911101-079,-080 & 0.12,0.10 \\ 911101-081,-082 & 0.17,0.17 \\ 911101-083,-084 & 0.08,0.07 \\ 911101-085,-086 & 0.06,0.06 \\ \text { (blank } & <0.001 \text { ) }\end{array}$

Naively assuming a normal distribution for the results, the average (mean/median) concentration of mercury in the extract is $0.29( \pm 0.28) \mathrm{mg} / \mathrm{L}$; thus the median value is greater than the $\mathrm{Hg}$ toxicity criterion $(0.20 \mathrm{mg} / \mathrm{L})$. These data apparently are the basis of the July 1992 advisory. Maskarinec presented no data for other elements (not run?), so no guidance is provided for (e.g.) $\mathrm{Pb}$ toxicity characteristic.

4. TCLP Testing for Crushed Fluorescent Lamps: Results from Y-12

Table 3 summarizes data from sampling events and analyses at the Y-12 Plant (data courtesy of Ken Cooper of Y-12 and Steve Astoria of Gilbert Commonwealth). These data corroborate the data from ORNL (Section 3, above): mean concentration of mercury in the TCLP extract was $0.27( \pm 0.16) \mathrm{mg} / \mathrm{L}$. One anomalous incidence was noted for exceedence of the toxicity criterion for cadmium (all other results for $\mathrm{Cd}$ were below the analytical detection limit). [note, however, that $\mathrm{Cd}$-doped phoshors have been used in some manufactured lamps to achieve a higher quantum efficiency; see Soules, T. F., and Hoffman, M. V. , 'Luminescent Materials (Phosphors)", in KirkOthmer Encyclopedia of Chemical Technology, 3rd ed., Vol. 14, pp. 527-545.]

At the bottom of the Table 3, we list the Universal Treatment Standard (UTS) criteria. Since the waste is designated 'D009' (characteristically hazardous for mercury), the waste is prohibited from land disposal until it is conditioned to meet the UTS criterion for mercury (i.e., the conditioned waste must yield a mercury concentration in the TCLP extract of $<0.025 \mathrm{mg} / \mathrm{L}$ ).

5. TCLP Testing for Crushed Fluorescent Lamps Stored at K-25

The data in Table 4 is a compilation of TCLP results provided courtesy of Tom Broussard. All 
available data for this population of waste sampled from storage drums $(\mathrm{N}=7)$ indicate that $\mathrm{Hg}$ in TCLP extract is below the TCLP toxicity criterion; labeling the storage drums 'D009" (hazardous waste, Hg-contaminated) was a management decision (justifiable, given the data from Tables 1-3). Although the number of data are small $(\mathrm{N}=7)$, we can fit data to a normal distribution, and compute the theoretical \% probability for exceedence of the $0.2 \mathrm{mg} / \mathrm{L}$ criterion. [Assuming all data are equally valid, the projected exceedance of criterion would be $\sim 0.5 \%$ of the population]. No other regulated metal, including $\mathrm{Cd}$, was determined to exceed the applicable toxicity criterion.

\section{Uranium Contamination in the Crushed Lamps}

Samples from the recent (1994/1995) Y-12 and K-25 sampling campaigns indicate that little or no significant uranium exists in the stored samples (Table 5). The uranium concentration in the solid debris averaged $<0.4 \mathrm{ug} / \mathrm{g}$ (or $<0.4$ parts-per-million, ppm). Only one sample (E950520-111, from Y-12) had sufficient uranium $(0.21 \mathrm{ug} / \mathrm{g})$ to permit an estimate of the isotopic abundance of $\mathrm{U}-235$; the value of $0.30 \mathrm{wt} \%$ is less than the abundance in natural (nonenriched) uranium (0.71 wt\% U-235).

Assuming $1 \mathrm{ug} U$ per gram of lamp material (i.e., $1 \mathrm{ug} / \mathrm{g}$, maximum background value reported in Table 4), and an isotopic abundance of $0.3 \mathrm{wt} \%$ (and thus a specific activity $\sim 4.8 \mathrm{E}-7 \mathrm{Ci} / \mathrm{g}$ ), the estimated activity in the debris solids is $\sim 0.5$ picocuries $(\mathrm{pCi})$ per $\mathrm{g}$. The Waste Acceptance Criteria for the Y-12 Industrial Landfill specifies that uranium must not be present in wastes at activities $>35 \mathrm{pCi} / \mathrm{g}$. 
Table 4. Data for TCLP Extraction of Crushed Fluorescent Lamps Stored at K-25 Site (Results given as $\mathrm{mg} / \mathrm{L}$ in extract)

\begin{tabular}{|l|l|l|l|l|l|l|l|l|l|}
\hline AnaLIS ID & $\mathrm{Hg}^{\mathrm{b}}$ & $\mathrm{Pb}^{\mathrm{c}}$ & $\mathrm{As}^{\mathrm{c}}$ & $\mathrm{Ba}^{\mathrm{c}}$ & $\mathrm{Cd}^{\mathrm{c}}$ & $\mathrm{Cr}^{\mathrm{c}}$ & $\mathrm{Ni}^{\mathrm{c}}$ & $\mathrm{Se}^{\mathrm{c}}$ & $\mathrm{Ag}^{\mathrm{c}}$ \\
\hline $940608-124$ & 0.033 & 1.0 & $<0.25$ & 0.73 & $<0.015$ & $<0.05$ & 0.97 & $<0.25$ & $<0.035$ \\
\hline $940608-123$ & 0.11 & 1.4 & $<0.25$ & 7.2 & $<0.015$ & 0.17 & 14 & $<0.25$ & $<0.035$ \\
\hline $940608-121$ & 0.056 & 1.1 & $<0.25$ & 1.1 & $<0.015$ & $<0.05$ & 1.6 & $<0.25$ & $<0.035$ \\
\hline $940608-122$ & 0.066 & 0.43 & $<0.25$ & 0.75 & $<0.015$ & 0.091 & 0.53 & $<0.25$ & $<0.035$ \\
\hline $940608-119$ & 0.065 & $<0.25$ & $<0.25$ & 4.2 & $<0.015$ & 0.23 & 9.8 & $<0.25$ & $<0.035$ \\
\hline $940608-120$ & 0.031 & $<0.25$ & $<0.25$ & 1.1 & $<0.015$ & $<0.05$ & 1.3 & $<0.25$ & $<0.035$ \\
\hline $910115-070$ & 0.169 & 0.07 & 0.054 & 1.4 & 0.0097 & $<0.01$ & 1.3 & $<0.05$ & $<0.01$ \\
\hline & & & & & & & & & \\
\hline $\begin{array}{l}\text { Median } \\
\text { Value }\end{array}$ & 0.076 & $\leq 0.64$ & $<0.25$ & 2.4 & $<0.015$ & $\leq 0.09$ & 4.2 & $<0.25$ & $<0.035$ \\
\pm 0.05 & \pm 2.5 & & \pm 5.4 & & & & \\
\hline $\begin{array}{l}\text { TCLP } \\
\text { Criterion }\end{array}$ & 0.20 & 5.0 & 5.0 & 100 & 1.0 & 5.0 & $\mathrm{NA}$ & 1.0 & 5.0 \\
\hline $\begin{array}{l}\text { UTS } \\
\text { Criterion }\end{array}$ & 0.025 & 0.37 & 5.0 & 7.6 & 0.19 & 0.86 & 5.0 & 0.16 & 0.30 \\
\hline
\end{tabular}

2 LMES Analytical Laboratory Information System Sample Identification Number

' Atomic Absorption Spectoscopy (EPA Method 7470)

'Inductively Coupled Plasma Spectrocopy (EPA Method 6010)

d Toxicity Characteristic Leaching Procedure (40 CFR 261.24)

- Universal Treatment Standard for hazardous waste: TCLP extract (nonwastewater) (60 FR 264) 
Table 3. Data for TCLP Extraction of Crushed Fluorescent Lamps Stored at Y-12 Site (Results given as $\mathrm{mg} / \mathrm{L}$ in extract)

\begin{tabular}{|c|c|c|c|c|c|c|c|c|}
\hline AnaLIS $\mathrm{ID}^{\mathrm{a}}$ & Hg & $\mathrm{Pb}$ & As & $\mathrm{Ba}$ & $\mathrm{Cd}$ & $\mathrm{Cr}$ & $\mathrm{Se}$ & $\mathrm{Ag}$ \\
\hline E950520-105 & 0.11 & $<0.50$ & $<0.50$ & $<10$ & $<0.10$ & $<0.50$ & $<0.50$ & $<0.50$ \\
\hline E950520-106 & 0.42 & $<0.50$ & $<0.50$ & $<10$ & $<0.10$ & $<0.50$ & $<0.50$ & $<0.50$ \\
\hline E950520-107 & 0.08 & $<0.50$ & $<0.50$ & $<10$ & $<0.10$ & $<0.50$ & $<0.50$ & $<0.50$ \\
\hline E950520-108 & 0.25 & $<0.50$ & $<0.50$ & $<10$ & $<0.10$ & $<0.50$ & $<0.50$ & $<0.50$ \\
\hline E950520-109 & 0.15 & $<0.50$ & $<0.50$ & $<10$ & $1.4 / 5.7$ & $<0.50$ & $<0.50$ & $<0.50$ \\
\hline E950520-110 & 0.19 & $<0.50$ & $<0.50$ & $<10$ & $<0.10$ & $<0.50$ & $<0.50$ & $<0.50$ \\
\hline E950520-111 & 0.13 & $<0.50$ & $<0.50$ & $<10$ & $<0.10$ & $<0.50$ & $<0.50$ & $<0.50$ \\
\hline E950520-112 & 0.26 & $<0.50$ & $<0.50$ & $<10$ & $<0.10$ & $<0.50$ & $<0.50$ & $<0.50$ \\
\hline E950520-113 & 0.56 & $<0.50$ & $<0.50$ & $<10$ & $<0.10$ & $<0.50$ & $<0.50$ & $<0.50$ \\
\hline E950520-114 & 0.57 & $<0.50$ & $<0.50$ & $<10$ & $<0.10$ & $<0.50$ & $<0.50$ & $<0.50$ \\
\hline E950520-115 & 0.37 & $<0.50$ & $<0.50$ & $<10$ & $<0.10$ & $<0.50$ & $<0.50$ & $<0.50$ \\
\hline E950520-116 & 0.19 & $<0.50$ & $<0.50$ & $<10$ & $<0.10$ & $<0.50$ & $<0.50$ & $<0.50$ \\
\hline E950520-117 & 0.24 & $<0.50$ & $<0.50$ & $<10$ & $<0.10$ & $<0.50$ & $<0.50$ & $<0.50$ \\
\hline Median Value & $\begin{array}{l}0.27 \\
\pm 0.16 \\
\end{array}$ & $<0.50$ & $<0.50$ & $<10$ & $\leq 0.55$ & $<0.50$ & $<0.50$ & $<0.50$ \\
\hline$\underset{B}{\text { TCLP Criterion }}$ & 0.20 & 5.0 & 5.0 & 100 & 1.0 & 5.0 & 1.0 & 5.0 \\
\hline UTS Criterion $^{c}$ & 0.025 & 0.37 & 5.0 & 7.6 & 0.19 & 0.86 & 0.16 & 0.30 \\
\hline
\end{tabular}

${ }^{a}$ LMES_Analytical Laboratory Information System Sample Identification Number

${ }^{b}$ Toxicity Characteristic Leaching Procedure (40 CFR 261.24)

' Universal Treatment Standard for hazardous waste: TCLP extract (nonwastewater) (60 FR 264) 
Table 5. Analysis for Uranium in Crushed Fluorescent Lamps (ug/g, or parts-per-million, by fluorometric analysis)

\begin{tabular}{|l|l|l|}
\hline Sample ID & Site & U, ug/g \\
\hline $940608-119$ & K-25 & $<1.0$ \\
\hline $940608-120$ & K-25 & $<1.0$ \\
\hline $940608-121$ & K-25 & $<1.0$ \\
\hline $940608-122$ & K-25 & $<1.0$ \\
\hline $940608-123$ & K-25 & $<1.0$ \\
\hline $940608-124$ & K-25 & $<1.0$ \\
\hline E950520-105 & Y-12 & $<0.05$ \\
\hline E950520-106 & Y-12 & 0.06 \\
\hline E950520-107 & Y-12 & $<0.045$ \\
\hline E950520-108 & Y-12 & $<0.053$ \\
\hline E950520-109 & Y-12 & $<0.047$ \\
\hline E950520-110 & Y-12 & $<0.048$ \\
\hline E950520-111 & Y-12 & 0.21 (U-235 assay: 0.3 wt\%) \\
\hline E950520-112 & Y-12 & $<0.039$ \\
\hline E950520-113 & Y-12 & 0.16 \\
\hline E950520-114 & Y-12 & 0.16 \\
\hline E950520-115 & Y-12 & $<0.05$ \\
\hline E950520-116 & Y-12 & $<0.059$ \\
\hline E950520-117 & Y-12 & $<0.061$ \\
\hline & & $<0.37$ \\
\hline Mean Value & & \\
\hline & & \\
\hline
\end{tabular}





\section{DISTRIBUTION \\ LMES/LMER}

Internal

1. J.K. Bailey

2. B. Barkenbus

3-12. W.D. Bostick (10)

13. K.T. Bowser

14. T.K. Broussard

15. C. H. Brown

16. D.H. Bunch

17. T.B. Conley

18. A.F. Diefendorf

19. L.R. Dole

20. C. H. Estes

21. RL. Fellows

22. J.N. Fiedor

23. A. D. Fleming

24. D.D. Gates

25. J.R. Hightower

26. D.P. Hoffmann
27. W.P. Huxtable

28. C. M. Kendrick

29. K.T. Klasson

30. D. Lyles

31. D.L. Mason

32. L.J. Mezga

33. C.M. Noakes

34. T.J. Oatts

35-38. A.S. Quist (3)*

39. G.F. Sellers

40. M.J.Shelton

41. C.M. Smith

42. M. L. Tull

43. R.R. Turner

44. D.B. Watson

45. S.T. Wright

External

46. S.J. Astoria - Gilbert Commonwealth

47. J. Farrell, Assistant Professor, Chemical and Environmental Engineering, University of Arizona, Tucson, AZ 85721.

48. D.F. Foust, GE Corporate Research and Development, Building K1, Room 5A24, Schenectady, NY 12301.

49. R.L. Helferich, Cercona, Inc., 314 Leo Street, Dayton, OH 45404.

50. D.C. Marozas, Sandia National Laboratory, Alburquerque, NM 87185.

51. V. Van Brunt, Professor, Chemical Engineering,University of South Carolina, Columbia, SC 29208 
